\title{
55. THE WESTERN ROCKALL PLATEAU: STRATIGRAPHY AND STRUCTURAL EVOLUTION
}

\author{
D.G. Roberts, Institute of Oceanographic Sciences, Wormley, Godalming, Surrey, United Kingdom \\ L. Montadert, Institut Français du Pétrole, Rueil-Malmaison, France \\ and \\ R.C. Searle, Institute of Oceanographic Sciences, Wormley, Godalming, Surrey, United Kingdom
}

\section{INTRODUCTION}

The Rockall Plateau is an extensive, shallow, topographically isolated area west of the British Isles (Figure 1), that is the only major microcontinent known in the North Atlantic Ocean; its margins were formed by the successive rifting and spreading phases that opened the North Atlantic.

Early geological and geophysical studies made on the Rockall Plateau by the U.K. Institute of Oceanographic Sciences (IOS), and the Department of Geodesy and Geophysics, University of Cambridge, established the continental structure that was first postulated by Bullard et al. (1965). These preliminary data provided the regional background for Sites 116 and 117 drilled by D/V Glomar Challenger during Leg 12 (Laughton, Berggren, et al., 1972). Subsequent seismic and magnetic surveys carried out by IOS, Lamont-Doherty Geological Observatory (L-DGO), and the U.S. Naval Oceanographic Office (USNOO) provided a comprehensive regional coverage of the Rockall Plateau. For the Leg 48 drilling program on the southwest margin, detailed multichannel seismic surveys of candidate drill sites were made by IOS, and were complemented by post-drilling multichannel seismic surveys made by the Comité d'Etudes Petrolières Marines (France) (CEPM).

In this paper, we discuss the regional geology and the structural and depositional history of the margins of the southwest Rockall Plateau and allude to problems that might be addressed by future drilling of passive margins.

\section{MORPHOLOGY OF THE ROCKALL PLATEAU}

The Rockall Plateau is an extensive shallow area measuring some $22 \times 10^{4} \mathrm{~km}^{2}$ at the 2000 -meter contour (Figure 1). The principal relief consists of the relatively shallow Rockall, Hatton, and George Bligh banks disposed around the deeper Hatton-Rockall Basin. Lorien, Edoras, and Fangorn banks are deeper shoals on the southern and westernmost parts of the plateau. Rockall Island is the sole subaerial expression.

The Hatton-Rockall Basin, location of DSDP Sites 116 and 117 , is an irregularly shaped basin elongated in a northeast-southwest direction and almost completely enclosed in the north by Hatton Bank, George Bligh Bank, and Rockall Bank. Within the basin, the dome-like shape of the basin floor, well-developed marginal channels, and a microrelief $(>10 \mathrm{~m})$ of ridges and channels are attributed to differential sediment deposition.
The margins of the Rockall Plateau to the east, southwest, and west are steep and fall to depths of 2500 meters. In the north however, the margins are ill-defined and merge with the foot slopes of the seamounts surmounting the low col between the Plateau and Faeroes Platform.

The western continental margin of Rockall Plateau extends as a clear topographic entity from $60^{\circ} \mathrm{N}$ to $54^{\circ} \mathrm{N}$ and its base is approximately defined by the 3000 -meter contour. The margin is, however, atypical because shelf and shelf break are absent. It consists of a series of poorly defined flat-topped and shelf-like features that are the crests of Hatton, Edoras, and Lorien banks, and a "continental slope." Major changes in the trend and morphology of the margin occur at $55^{\circ} 30^{\prime} \mathrm{N}$. North of this latitude, the margin trends northeast-southwest and parallel to the oldest magnetic anomalies recorded in the adjacent ocean crust. True canyons are absent on the slope. The present relief of the slope, which consists of minor channels cutting the Hatton sediment drift, has been largely fashioned by differential sediment deposition under the influence of northward flowing Labrador Sea water (Roberts, 1975). South of $55^{\circ} 50^{\prime} \mathrm{N}$, the margin is right-angled in plan and consists of a steep east-west scarp and a gentler north-south slope. These major changes in trend and morphology are related to the different episodes of rifting and transform faulting of Rockall Plateau discussed below.

\section{REGIONAL GEOLOGY AND TECTONIC HISTORY}

Early geological and geophysical studies made on the Rockall Plateau were dedicated toward establishing the continental structure and composition previously postulated by Bullard et al. (1965). Deep seismic refraction profiles found continental seismic velocities and mantle depths of 33 and $22 \mathrm{~km}$ (Figure 2) beneath the Rockall Bank and Hatton-Rockall Basin, respectively (Scrutton, 1970, 1972; Scrutton and Roberts, 1971). Gravity models (Scrutton, 1972) based on these data have confirmed previous suggestions (Bullard et al., 1965; Roberts, 1970, 1971) that the entire plateau is a microcontinent. More recent geophysical studies have suggested that another continental fragment may underlie the Paleocene lavas of the Faeroe Islands (Bott et al., 1971; Casten, 1973; Bott et al., 1974; Casten and Nielsen, 1975). Laxfordian and Grenvillian granulites dredged and drilled on Rockall Bank have proved the presence of continental rocks (Roberts, Matthews and Eden, 1972; Roberts, Ardus, and Dearnley, 1973; Miller, et al., 1973). 


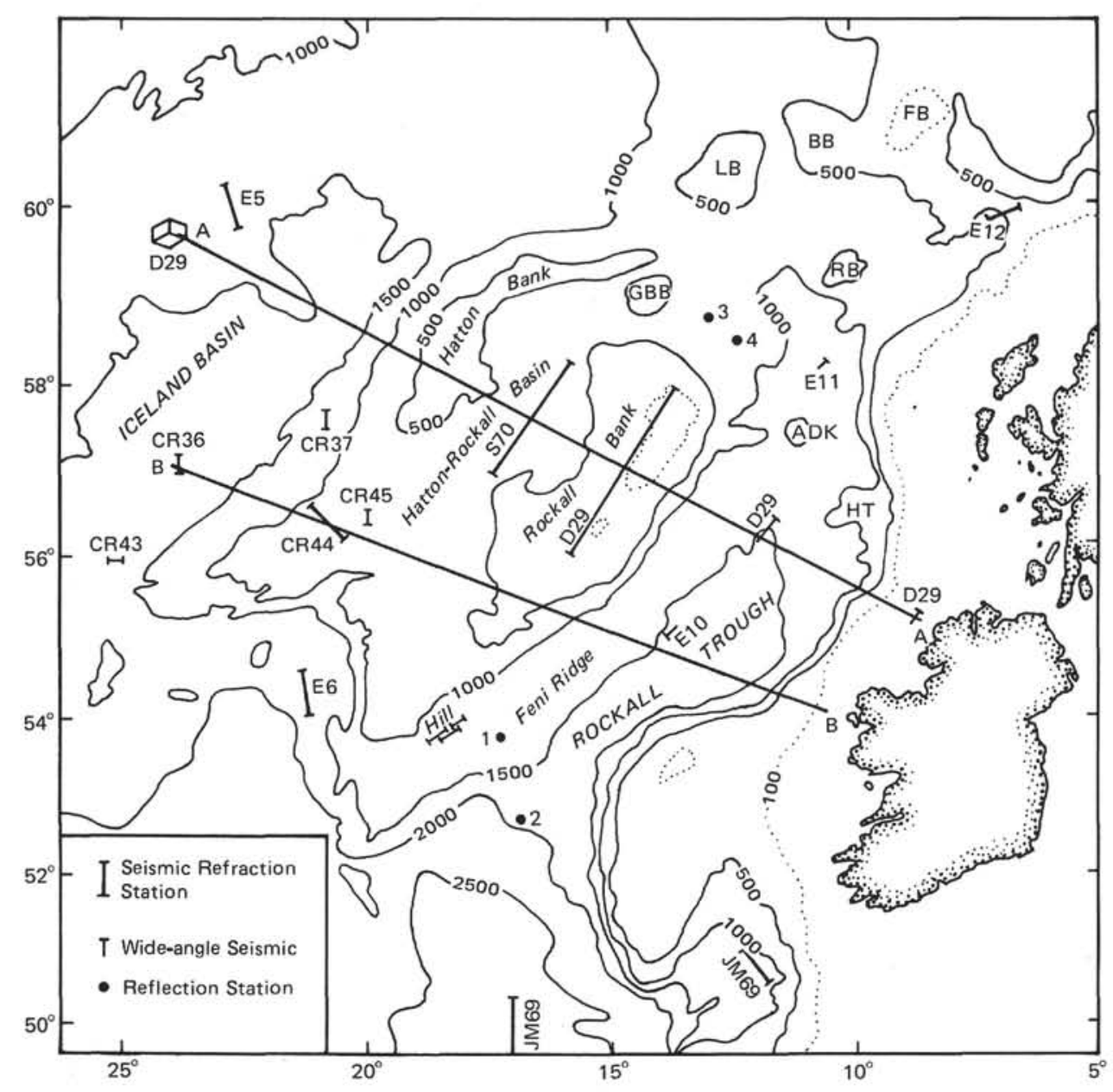

Figure 1. Bathymetry of the Rockall Plateau showing location of seismic refraction profiles and gravity profile A.A. of Figure 2.

The presence of oceanic magnetic anomalies (Figure 3) and a typical oceanic seismic structure suggests that oceanic crust underlies the deep basins to the west and southwest of Rockall Plateau (Ewing and Ewing, 1958; Gaskell et al., 1958; Vogt and Avery, 1974). To the east, the body of the geophysical evidence suggests that oceanic crust underlies part of the Rockall Trough (Roberts, 1974, 1975).

Syntheses of the plate tectonic evolution of the North Atlantic Ocean based principally on the identification of magnetic isochrons show that three distinct phases of rifting and spreading have resulted in the present structural isolation of the plateau (Vogt et al., 1971; Laughton, 1971; Vogt and Avery, 1974; Le Pichon, et al., 1971; Olivet et al., 1974; Srivastava, 1978; Kristoffersen and Talwani, 1978).

Triassic distension, extending over the North Atlantic region and well documented in Greenland and northwest Europe, was the earliest rifting of direct relevance (Ziegler, 1974). Following a prolonged period of relative quiescence characterized by only minor movements, major rifting in Late Jurassic/Early Cretaceous time (Cimmerian sl.) led to the spreading of the Bay of Biscay in Aptian time (Ziegler, 1975; Montadert et al., this volume). Opening of the Rockall Trough (Figure 4) apparently postdates the initiation of spreading in Biscay, although the duration and kinematics of spreading in the trough remain obscure (Roberts, 1975; Montadert et al., this volume).

By anomaly 31-32 time, spreading ceased in the Rockall Trough and the axis shifted to the west, opening the Labrador Sea and spreading Greenland-Rockall away from North America (Figure 4). Spreading evidently began earlier in the southern Labrador Sea than in the north, although the rifting may have commenced as early as Early Cretaceous (Srivastava, 1978). This rifting and spreading phase was responsible for the creation of the Gibbs fracture zone and several of the prominent offsets in the margin of the Labrador Sea such as the Cartwright fracture zone. The prominent east-west scarp of the southwest margin of Rockall Plateau may also have formed at this time (Le Pichon et al., 1972; Laughton, 1972; Srivastava, 1978). The adjacent oceanic magnetic anomalies are truncated at the base of the scarp (Figures 3,5) and become younger westward from anomaly 32 , close to Lorien Bank, to anomaly 24 at $25^{\circ} 30^{\prime} \mathrm{W}$ (Figure 4). This suggests that the east-west margin may have been a continental margin transform fault active between 76 and $52 \mathrm{~m}$.y. In contrast, the adjacent north/south margin to the west of Lorien Bank lies approximately parallel to these anomalies and it formed by rifting to become a passive margin at the onset of spreading at $76 \mathrm{~m} . \mathrm{y}$. (Figures $3,4,5$ ). This offset in the 

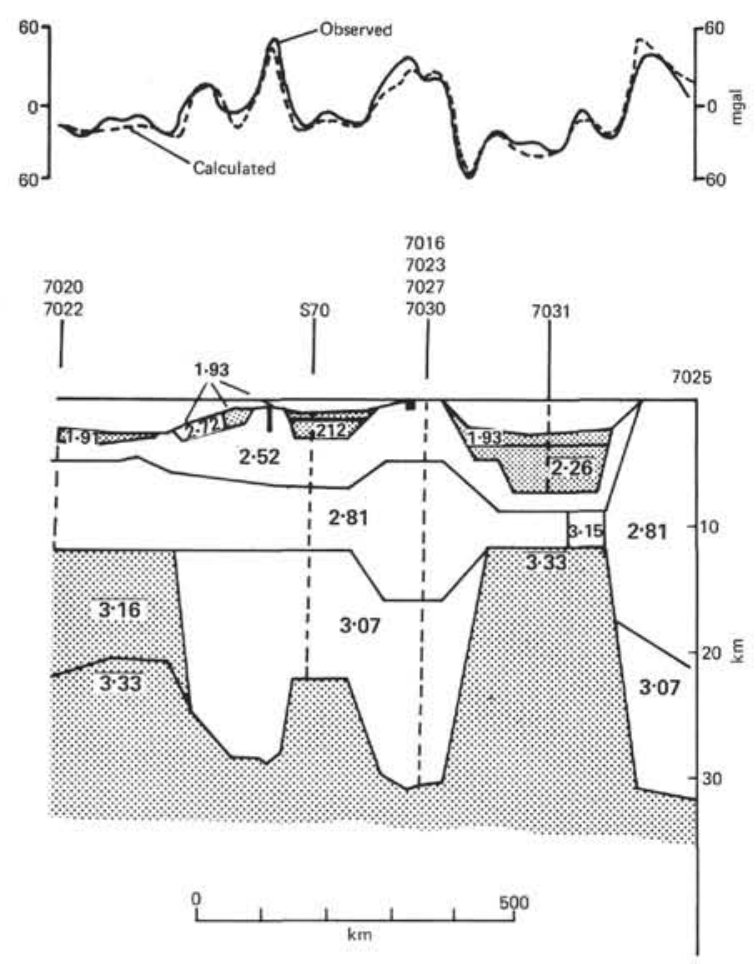

Figure 2. Structure of the Rockall Plateau modeled from gravity and available refraction data (redrawn from Scrutton, 1972).

margin of the embryonic Labrador Sea may have been structurally controlled by the eastward continuation of the Grenville Front (Miller et al., 1973; Roberts, 1974).

Formation of this right-angled margin clearly predates the adjacent northeast/southwest margin to the north where spreading began at $52 \mathrm{~m} . \mathrm{y}$. (Figure 3 ). However, this early phase of opening of the Labrador Sea may have been partly contemporaneous with the rifting between Greenland and Rockall Plateau that initially structured the northeast/ southwest part of the margin. Srivastava (1978) has observed differences in the poles of rotation for the Atlantic and Labrador Sea that suggest the rifting may have begun as early as Campanian time. Evidence of volcanism during the Late Cretaceous and Paleocene lends support to this observation (Sabine, 1969; Roberts, 1969; Roberts et al., 1973).

Discrepancies in the fit between Greenland and the Rockall Plateau, as well as evidence of linear anomalies (Laughton, 1971; Srivastava, 1978) pre-dating anomaly 24, suggest that about $60 \mathrm{~km}$ of ocean crust may have accreted prior to anomaly 24 . Movement of this small magnitude, however, may easily have been taken up by crustal attenuation rather than spreading.

Active sea-floor spreading between Greenland and Rockall, which began at 52 m.y. (anomaly 24) and completed the isolation of the Rockall Plateau, was associated with the initiation of a triple junction south of Greenland (Figures 3,4). Spreading continued in the Labrador Sea until 40 m.y. when the triple junction became extinct (Figures 3, 4). On the Reykjanes Ridge, this change was marked by a deceleration and a reorientation of the spreading to a north-south axis cut by closely spaced east-west fracture zones (Vogt and Avery, 1974). At about $10 \mathrm{~m} . \mathrm{y}$. acceleration in the spreading was accompanied by a reorientation to a northeast/southwest axis cut by sparse fracture zones.

\section{STRUCTURE AND STRATIGRAPHY OF THE SOUTHWEST ROCKALL PLATEAU}

\section{Introduction}

A regional synthesis of the marine geology of the Rockall Plateau and Trough, based principally on seismic reflection profiles with stratigraphic correlation provided by DSDP Sites 116 and 117, has been presented by Roberts (1974, 1975). New data (Figure 6) used in this paper include multichannel profiles acquired by IOS, the IFP-CEPM group, and single-channel seismic profiles obtained by Ruddiman (1972) and L-DGO (Talwani et al., 1974; Ewing, personal communication, 1976). In addition, detailed magnetic surveys of part of the Rockall Plateau made by the USNOO (Vogt and Avery, 1974), have been modified and extended (Figure 3 ) using data obtained by IOS and L-DGO (Roberts and Jones, 1975).

In his discussion of the distribution of sediments and the regional structure of the Rockall Plateau, Roberts (1974, 1975) recognized three seismic units: "basement," a "pre-R4 series," and a "post-R4 series." The latter are separated by a prominent reflector, $\mathrm{R} 4$, found on the plateau and in the surrounding areas. This reflector, which also corresponds to an unconformity, was penetrated at DSDP Sites 116 and 117 where it is of Oligocene-Eocene age (Laughton, Berggren, et al., 1972). Reflector R4 was also penetrated at Site 403 where it arises from a tuff bed of early Eocene age just beneath two closely spaced unconformities between middle Eocene and Oligocene beds, and Oligocene and upper Miocene beds, respectively (Montadert, Roberts, et al., this volume). At Site 406, reflector R4 was associated with an upper Eocene to middle Oligocene hiatus (Figure 7). Roberts. (1975) attributed reflector R4 to regional erosion and/or non-deposition. For ease of discussion, we shall follow the same nomenclature in discussing the stratigraphy and structure in terms of seismic profiles and the results from DSDP Legs 12 and 48 (Laughton, Berggren, et al., 1972; Montadert, Roberts, et al., this volume).

\section{Basement Structure}

The geology of the basement of the southwest margin is conveniently discussed in terms of three separate structural elements: the Rockall Plateau, the continental margins, and the oceanic crust.

\section{Rockall Plateau}

The principal structural elements of the Rockall Plateau are the Hatton-Rockall Basin and the surrounding basement highs that comprise the shallow banks (Figure 5). Rockall Bank is composed of pre-Cambrian granulites locally overlain by lower Tertiary and Upper Cretaceous lavas (Sabine, 1965; Roberts, 1969; Roberts et al., 1973). On the evidence of high refraction velocities and derived 


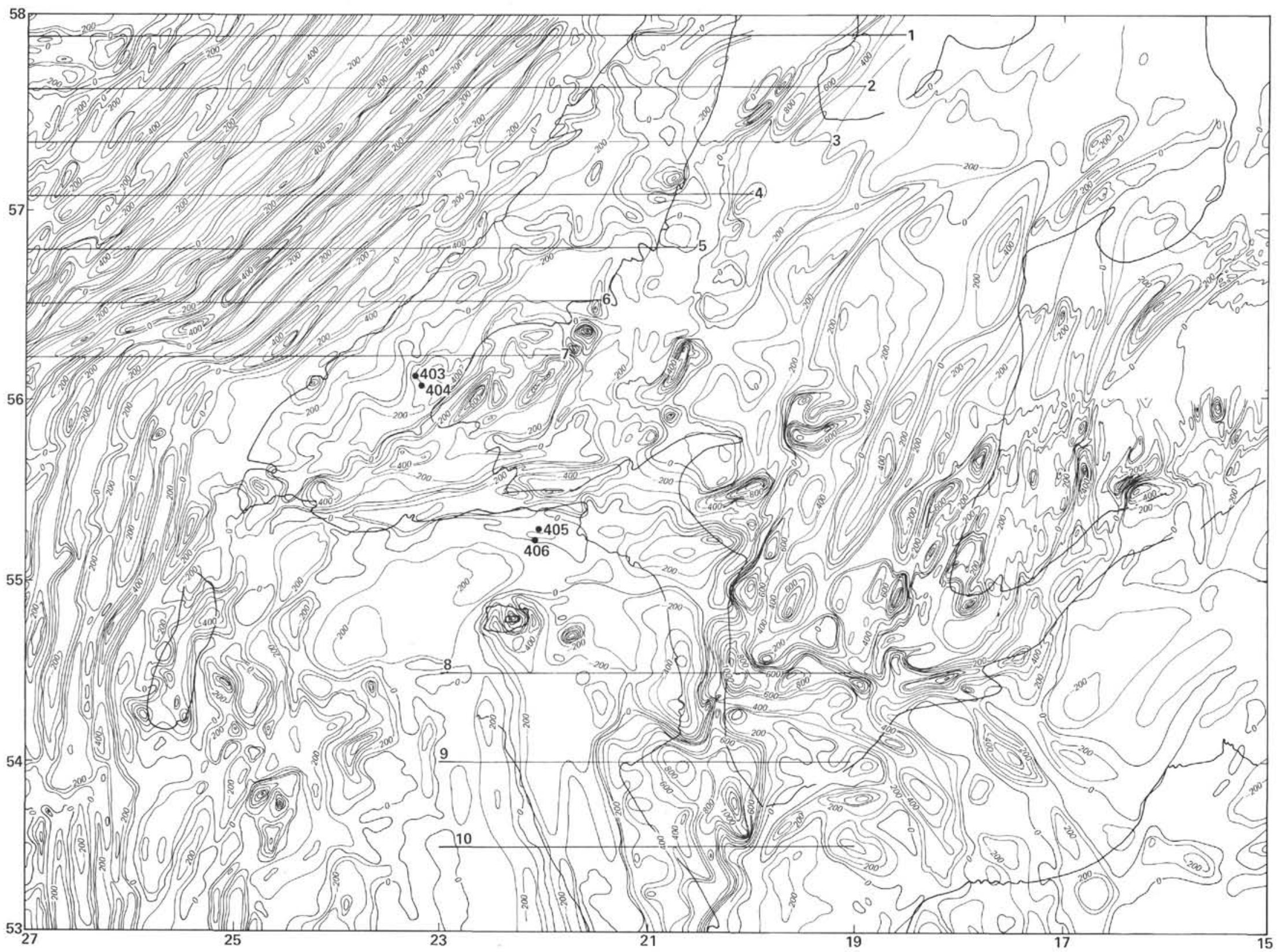

Figure 3. Magnetic anomaly contour map of the western Rockall Plateau (based on Vogt and Avery, 1974 and Roberts and Jones, 1975). Contour interval 100 \%. Leg 48 Site 403 . Numbers refer to profiles of Figure 11. 
pre-Cambrian granulites and lavas encountered in DSDP Holes 403 and 404, Hatton Bank and Edoras Bank may have a similar composition (Gaskell et al., 1958; Montadert, Roberts, et al., this volume). In both cases, large gravity anomalies and short wavelength magnetic anomalies of high amplitude (Figure 3 ) suggest the presence of shallow intrusive and extrusive centers (Roberts, 1969; Scrutton, 1972). Post-Eocene sediments are thin or absent on these flat-topped banks.

Travel times to basement show that the Hatton-Rockall Basin is irregular in plan (Figures 5, 8) and, in section, is either a broad downflexure with superposed faulting or a wide graben (Figures 9a, b). At $59^{\circ} \mathrm{N} 18^{\circ} \mathrm{W}$, the basin trends northeast-southwest parallel to the northwest margin of the plateau. At $57^{\circ} \mathrm{N}$, the main part of the basin consists of a $60-\mathrm{km}$-wide graben underlain by an irregular relief of about $0.5 \mathrm{~s}$ that may be indicative of block faulting.

At $57^{\circ} \mathrm{N}$, there is a major change in the trend, structure and depth of the Hatton-Rockall Basin. The fault zone defining the western edge of the basin becomes less well defined south of $57^{\circ} \mathrm{N}$, although the basin axis can be followed somewhat further south, until it intersects the northward prolongation of the Hatton-Fangorn High. The eastern boundary faults change trend to north northeastsouth southwest and progressively decrease in throw southward from $1.75 \mathrm{~s}$ at $57^{\circ} \mathrm{N}$ to about $0.3 \mathrm{~s}$ in the irregular basement low between Rockall Bank and Lorien Bank. A faulted western margin is no longer apparent and the basement rises westward to form a broad high underlying the crest of the slope between Fangorn Bank and Lorien Bank. On the basis of magnetic evidence, this high trends north northeast-south southwest and first develops at $57^{\circ} \mathrm{N}$. The complex magnetic anomaly pattern associated with the high (Figures 3,5) may reflect the presence of numerous faults of variable trend as well as variations in basement depth and composition. The high and the eastern boundary fault are terminated near $53^{\circ} 10^{\prime} \mathrm{N}$, by a west northwest-east southeast trending magnetic lineation apparently linked to an offset in the west margin (Figures 3, 5).

\section{The Northern Rifted Margin}

The Hatton Bank comprises a broad flat-topped basement high near $58^{\circ} \mathrm{N}$ that narrows southward into one of a series of northeast-southwest trending basement ridges associated with magnetic anomalies of that trend (Figures 3,5 ). These ridges parallel both the slope and the linear magnetic anomalies recorded in the adjacent oceanic crust. The outermost ridge occurs at the base of the slope and may be at or close to the continent/ocean boundary (Figures 10 [in back pocket, this volume], 11). The ridges and intervening basins are probably bounded by faults, sometimes expressed as the prominent topographic scarps forming the western edge of Hatton Bank and Edoras Bank. The narrow basin underlying the foot of the slope west of Edoras Bank is here called the Edoras Basin. Towards the south, the ridges and basins curve westward to converge with the west southwest-east northeast trend of the fracture zone (Figure 5). The basement generally increases in depth toward the southwest (Figure 8) although Edoras Bank is a prominent flat-topped feature at about $1.7 \mathrm{~s}$ below sea level.

Little is known of the deeper structure and composition of the basement in this region. From gravity models, Scrutton
(1972) derived a Moho depth of about $28 \mathrm{~km}$. The available refraction data show great variability in basement velocity, e.g., nearby stations CR $44 \mathrm{~A}$ and 45 (Figure 1) show basement velocities of 5.5 and $4.7 \mathrm{~km} / \mathrm{s}$, respectively.

Although this margin is considered to have formed by rifting, it is important to emphasize that there is a contrast in the general structure of the basement of the western margin of Rockall Plateau with that observed in Biscay. The tilted and rotated fault blocks with consistent downthrow toward the ocean have not been observed. In this area, the broad graben of the Hatton-Rockall Basin is flanked oceanward by large horsts comprising Hatton Bank and Edoras Bank and underlying the base of the slope.

\section{The Transform Margin}

The right-angled margin to the south of $55^{\circ} 50^{\prime} \mathrm{N}$ is considered to have formed by transform faulting and rifting along west southwest-east northeast and north northwestsouth southeast trends. The basement of the east-west transform margin is structured into a series of west southwest-east northeast basins that curve into northeast-southwest faults controlling the adjoining margin to the north (Figure 5). The largest fault that defines the continent/ocean boundary along the transform has an apparent throw of about 6.5 to $7.5 \mathrm{~km}$ (Figure 8). On magnetic and topographic evidence (Figures 3, 5), the major fault appears to be offset near $24^{\circ} \mathrm{W}$ suggesting that a short rifted margin is present, linking the major transform to a second some $30 \mathrm{~km}$ further north. The major fault can be traced eastward as far as $20^{\circ} \mathrm{W}$ although its extension beyond and into the Hatton-Rockall basin remains equivocal (Figure 5). The fault may terminate against the prominent north northwest-south southeast fault defining the adjoining rifted margin. The presence of Fangorn Bank, at the junction of these trends and an irregular basement high considered to be an intrusive center, may not be coincidental (Figures 3, 5).

\section{The Southern Rifted Margin}

The prominent north northwest-south southeast trending fault that controls the western flank of the Hatton-Fangorn high has a throw of about $3.0 \mathrm{~s}$, and can be followed as far south as $53^{\circ} \mathrm{N}$, but does not appear to be offset by the west northwest-trending magnetic lineament at $53^{\circ} 10^{\prime} \mathrm{N}$. South of this latitude, the throw of the fault decreases from $3.0 \mathrm{~s}$ to $2.0 \mathrm{~s}$, and an area of positive and irregular anomalies adjoins the base of the slope in contrast to the linear negative anomaly observed further to the north (Figures $3,11)$. The irregular positive anomaly is bounded further to the west by a prominent north northeast-south southwest fault parallel to the main margin fault. The data suggest that deeply subsided continental crust continues some $50 \mathrm{~km}$ to the west of the major scarp and that an offset in the margin may be present at $53^{\circ} 10^{\prime} \mathrm{N}$.

\section{The Oceanic Crust}

Within the oceanic crust, it is convenient to discuss the age of the magnetic anomalies and their spatial relationship to the different rifted and transform margins of southwest Rockall. The oldest magnetic anomaly clearly identified adjacent to the northwest margin is anomaly 24 (Figures 3, 11) (52 m.y. - Hailwood et al., this volume). This 

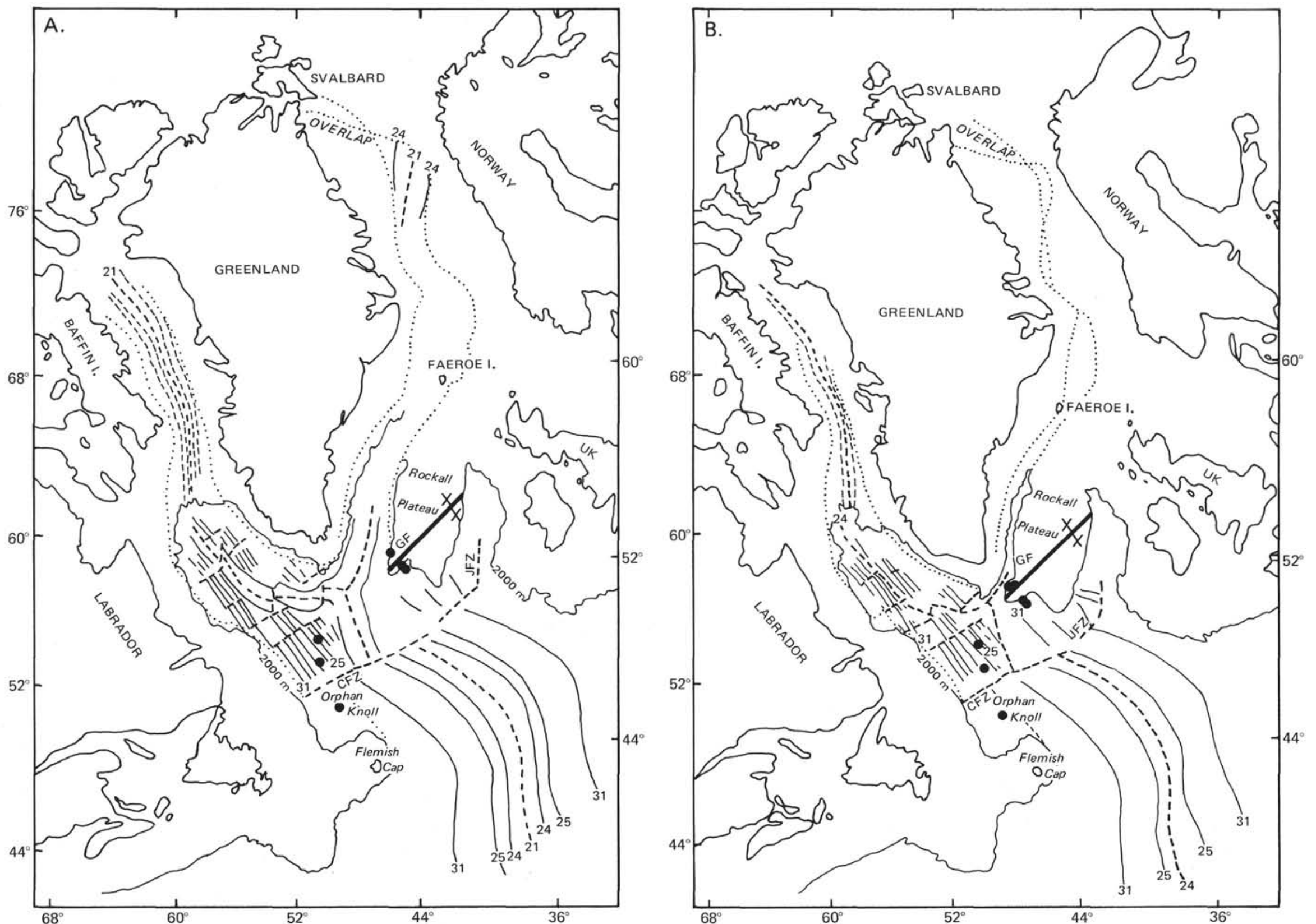

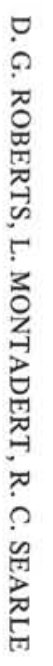

Figure 4. Paleogeographic positions of Greenland, Europe, and the Rockall Plateau at (A) anomaly-21 time, (B) anomaly-24 time, (C) anomaly-25 time, and (D) anomaly-32 time. GF: Grenville Front; J.F.Z: Jean Charcot Fault Zone; CFZ: Charlie Fracture Zone. Heavy dots: DSDP sites (after Srivastava, 1978). 

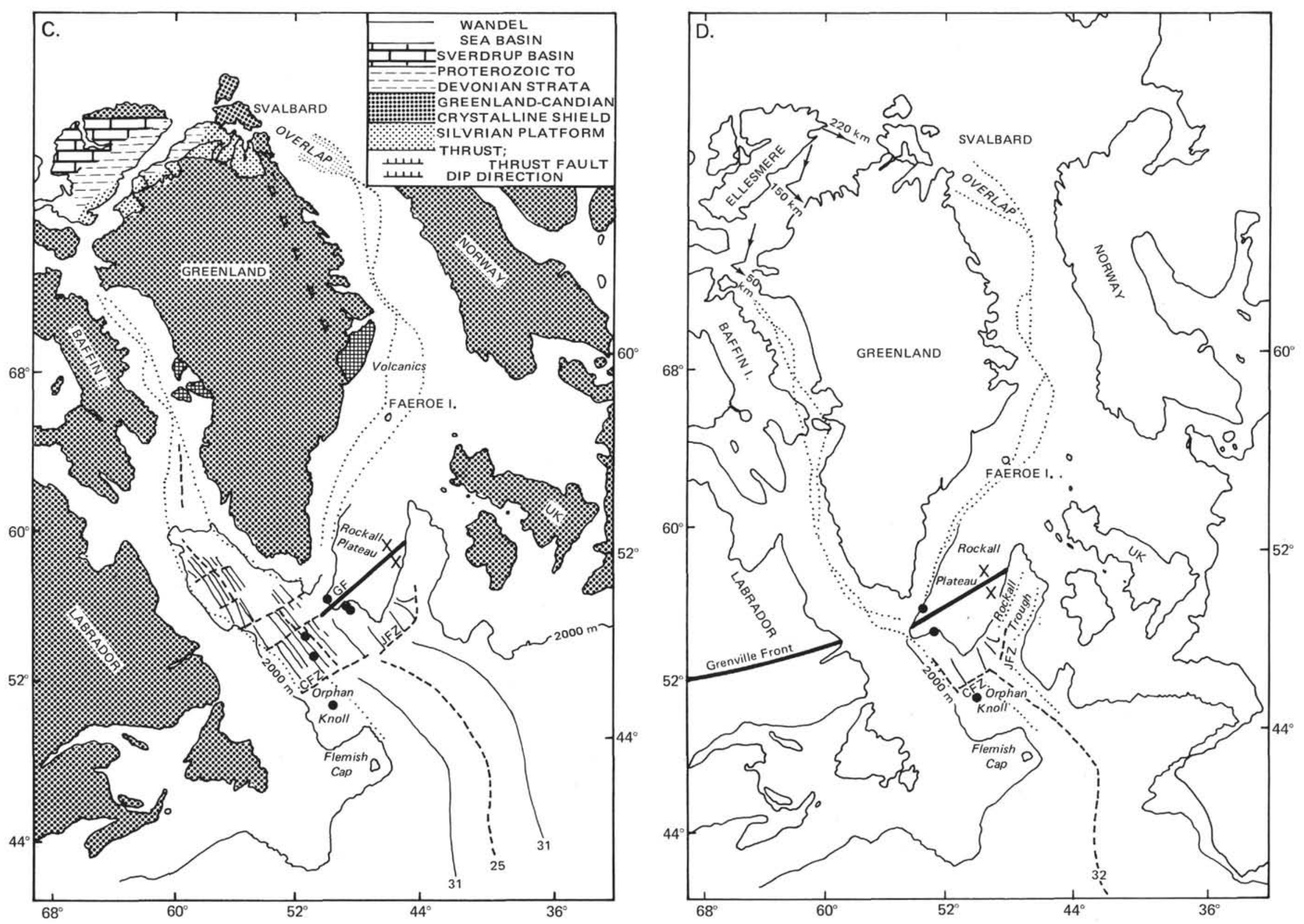

홍 Figure 4. (Continued). 


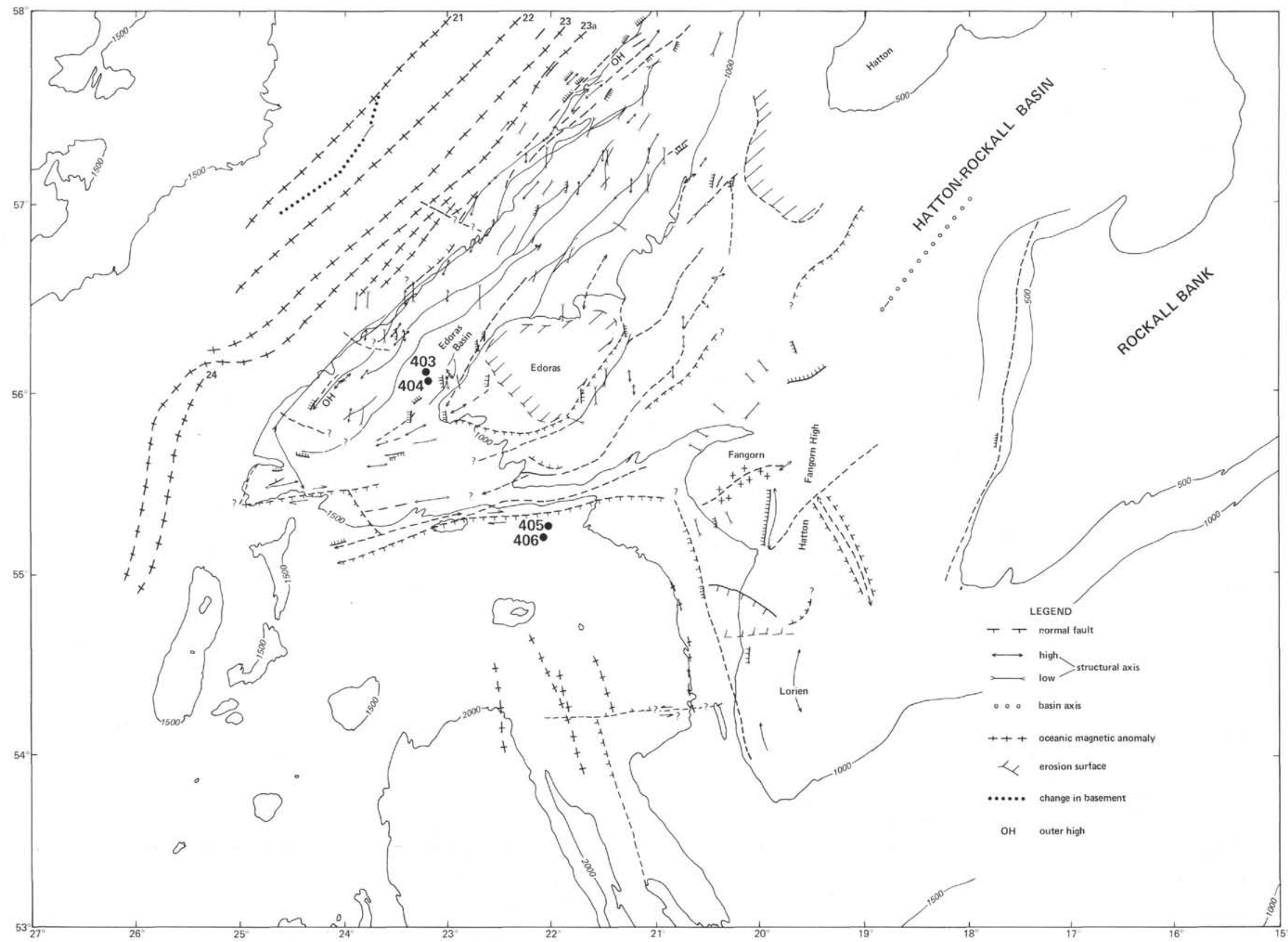

Figure 5. Principal structural elements of the southwestern Rockall Plateau based on seismic reflection profiles and magnetic data. 


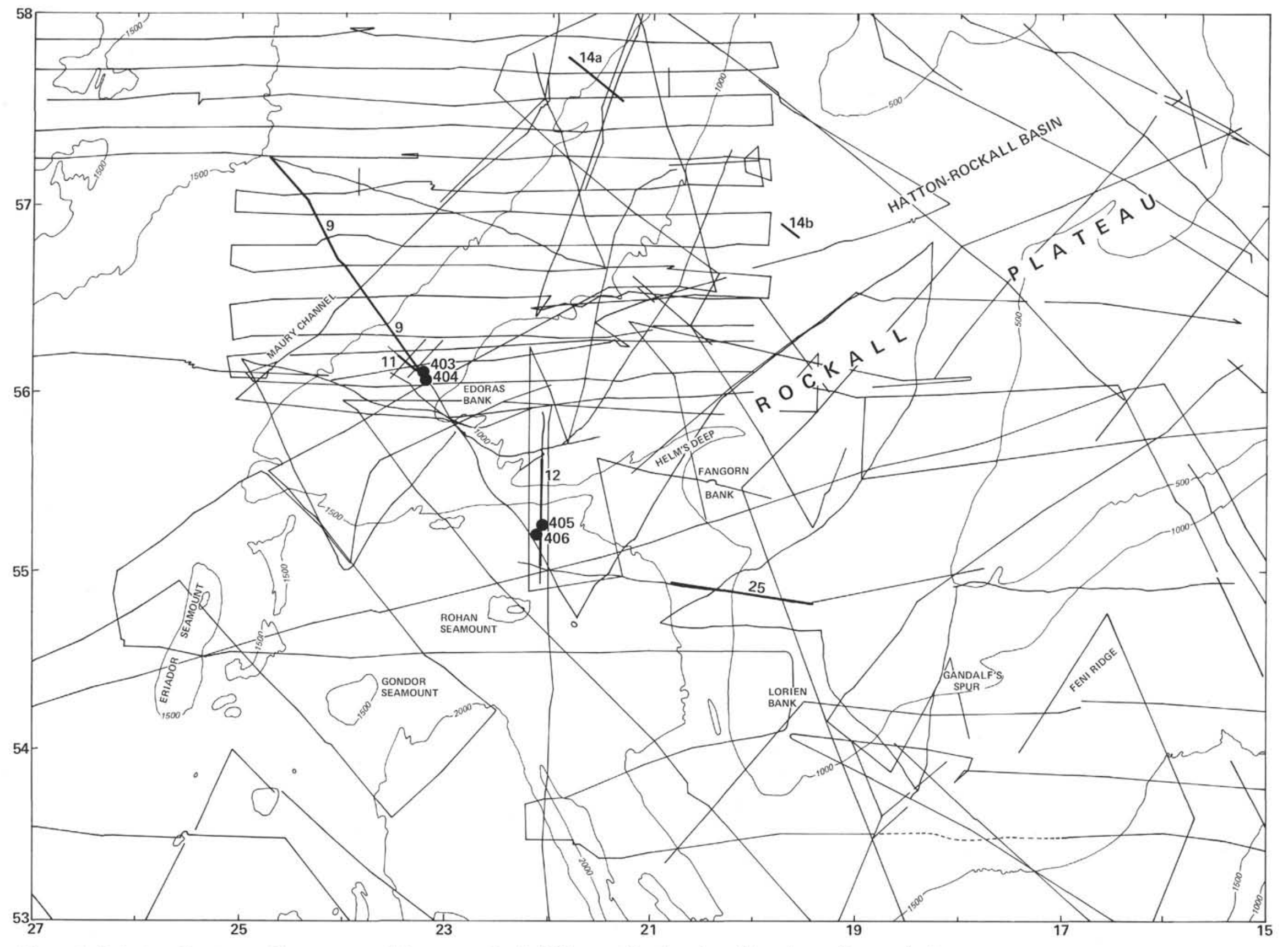



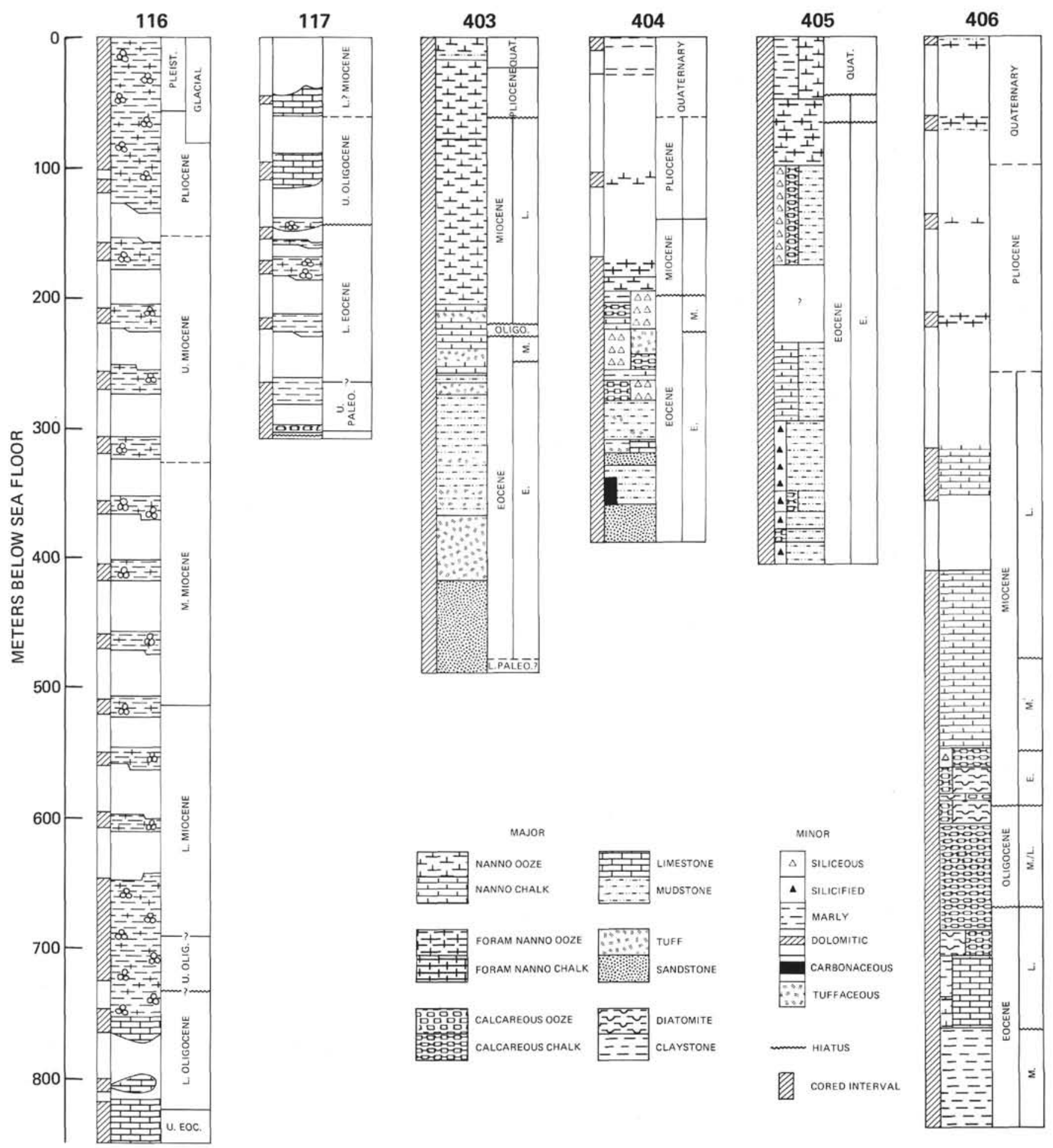

Figure 7. Summary stratigraphy of Leg 12 and Leg 48 DSDP sites on the Rockall Plateau.

anomaly adjoins the base of the slope between the northeastern arm of the triple point at $50^{\circ} 10^{\prime} \mathrm{N}$ and $57^{\circ} \mathrm{N}$ (Figures 3, 5). North of this latitude, no clearly defined linear positive anomaly corresponding to anomaly 24 can be mapped, and the oldest anomaly adjoining the base of the slope is the younger anomaly $23 A(51 \mathrm{~m} . \mathrm{y}$. - Hailwood et al., this volume). South of $56^{\circ} 10^{\prime} \mathrm{N}$, anomaly 24 diverges from the base of the slope towards the triple point and in the intervening space, a linear negative and a broad positive anomaly are present that do not follow the northeast-southwest trend of the adjacent margin or its underlying basement structure. However, a reversed seismic refraction profile in this area (CR.36, Gaskell et al., 1958) yielded a typical oceanic structure. Anomalies 24 through 20 collectively form a well-developed linear sequence formed during the first phase of spreading on the Reykjanes Ridge. Seismic 


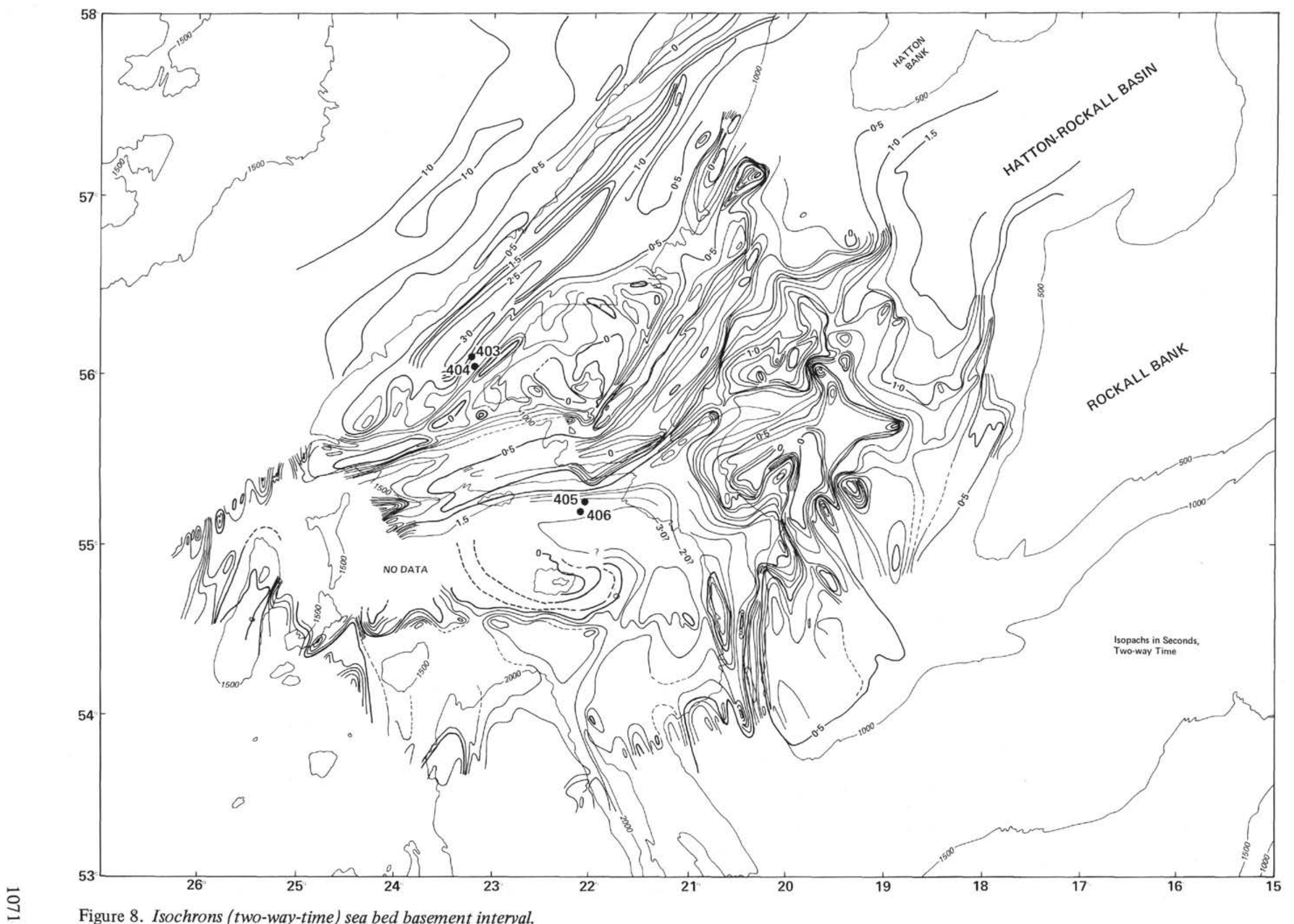

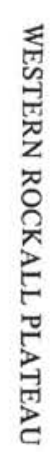



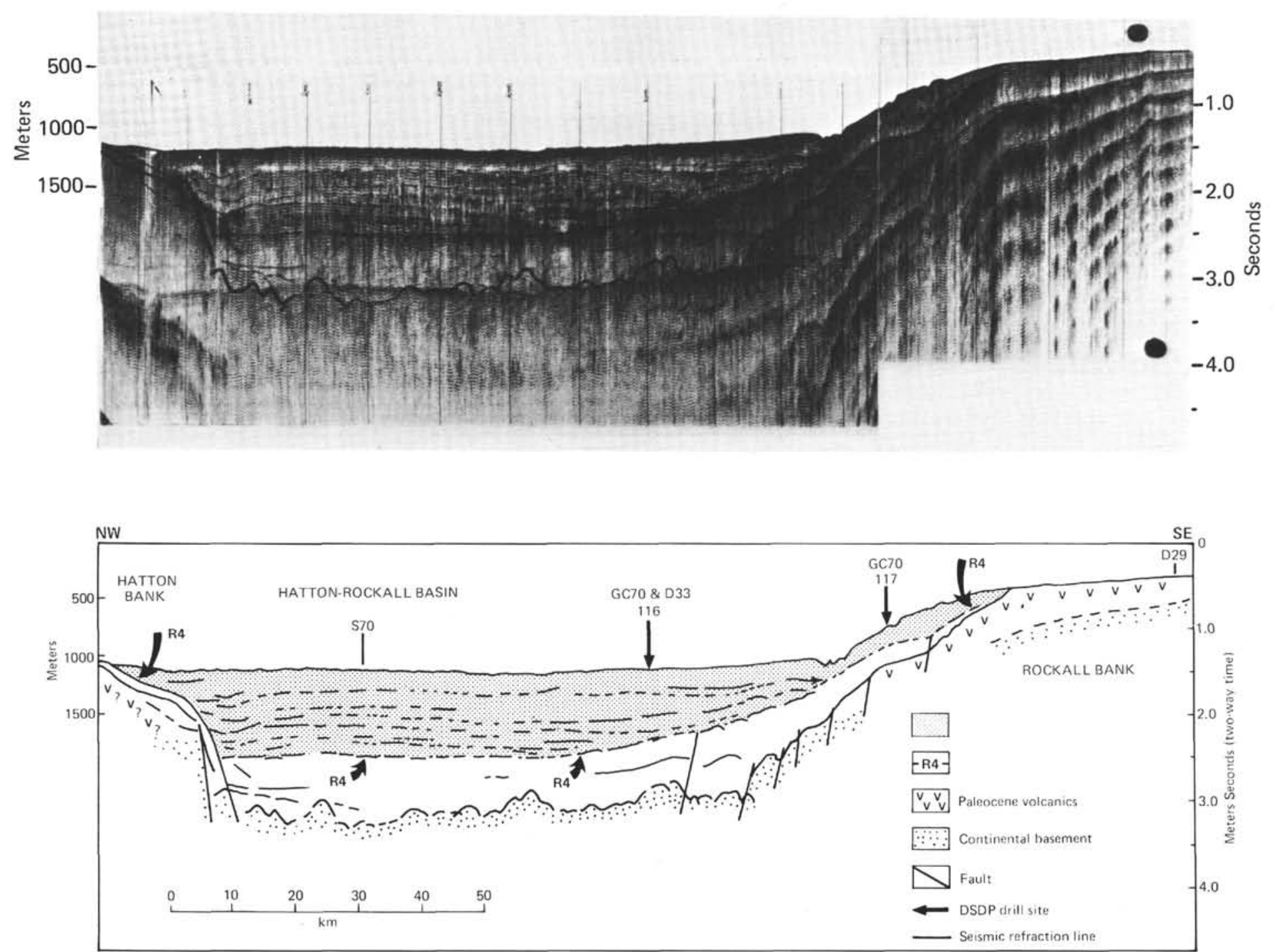

Figure 9a. Single-channel seismic reflection profile across the northem Hatton-Rockall Basin. 

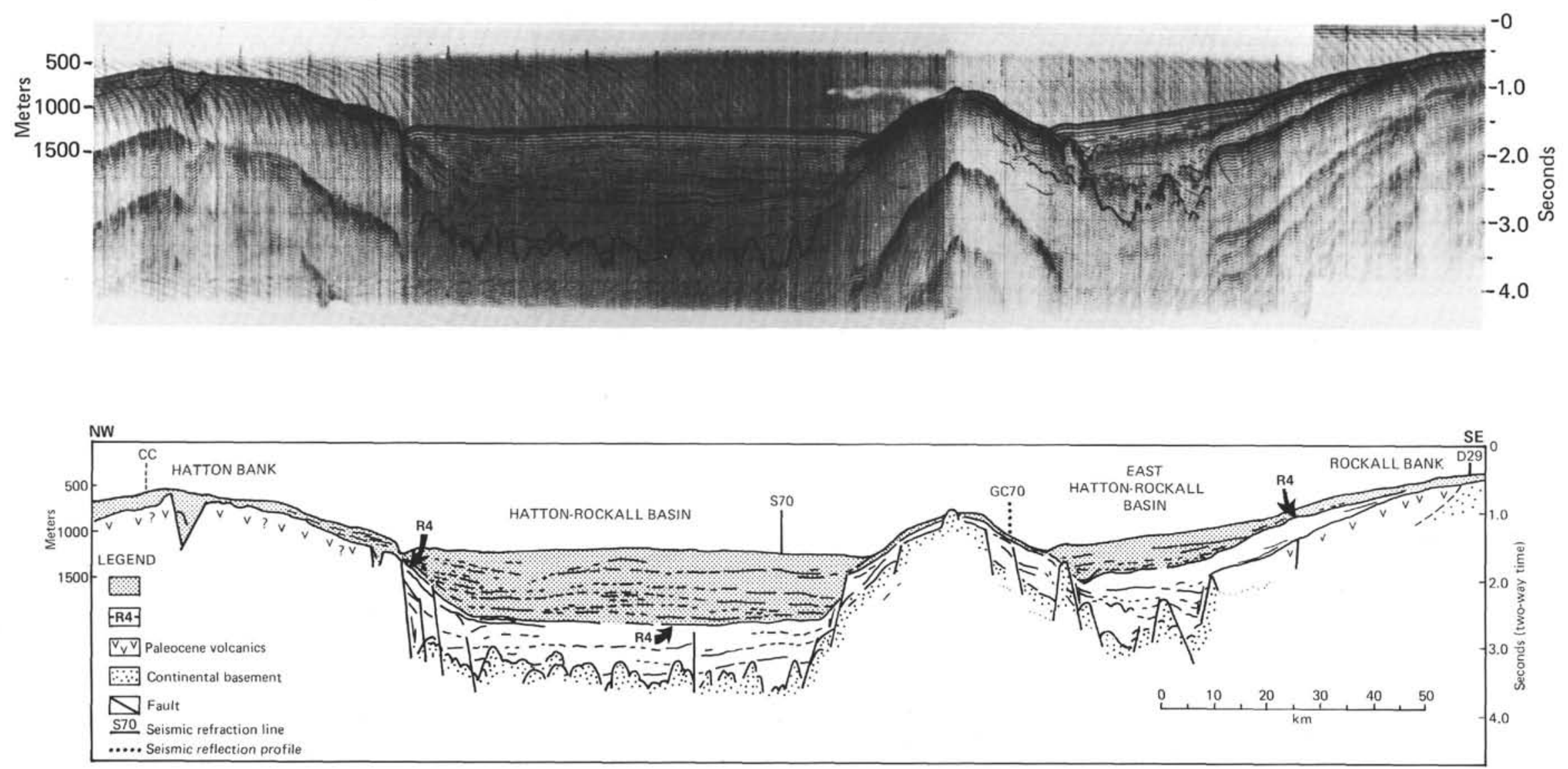

Figure 9b. Single-channel seismic reflection profile across the central Hatton-Rockall Basin. 

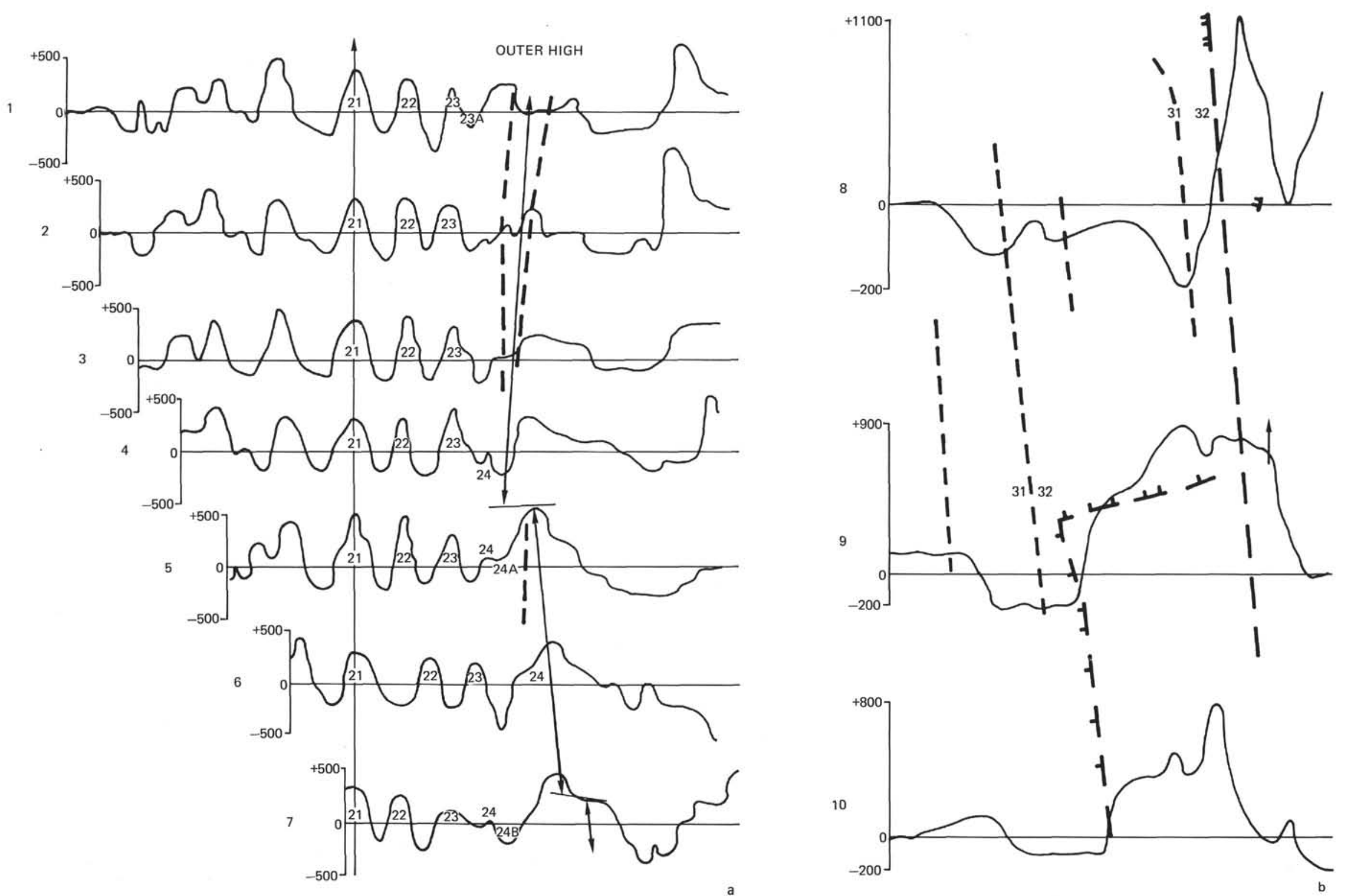

Figure 11. (A) East-west magnetic anomaly profiles across the $52 \mathrm{~m} . y$. old margin between $58^{\circ} 00^{\prime} \mathrm{N}$ and $55^{\circ} 30^{\prime} \mathrm{N}$. (B) East-west magnetic anomaly profiles across the 76 m.y. old margin between $55^{\circ} 30^{\prime} \mathrm{N}$ and $52^{\circ}$. Profiles are located on Figure 3. Heavy dashed lines indicate position of outer high or prominent fault adjacent to the continent/ocean boundary. 
refraction profiles show a typical oceanic structure beneath an unusually flat acoustic basement (Figure 10) observed by Scrutton and Roberts (1970) and by Ruddiman (1972).

Within the rectangular embayment of the margin south of $55^{\circ} 50^{\prime} \mathrm{N}$, the magnetic anomalies are more complex. Obvious and distinctive changes in anomaly pattern at $55^{\circ} 10^{\prime} \mathrm{N}$ and $53^{\circ} 10^{\prime} \mathrm{N}$ are associated with transform offsets of the margin (Figures 3, 5). The linear magnetic anomalies from the south do not terminate directly against the transform fault scarp, but are truncated against a broad, 40-km-wide area of flat magnetic anomalies trending parallel to the transform margin. The greatest basement depths coincide with this area of broad anomalies, which are interpreted as marking the zone of oceanic crust effectively demagnetized by shear along the transform. In the linear anomaly sequence to the south, the oldest anomaly which is adjacent to the continent is interpreted to be anomaly 31-32, (Figures 3, 11). Between anomalies 31-32 and 24, a complex but apparently linear pattern of north northwest-south southeast-trending anomalies characterized by small offsets (which do not affect anomaly 31-32) is present. In contrast, the post-anomaly 24 anomalies trend north-south and are not offset. The complex pattern may have been produced by a gradual re-orientation in spreading associated with the rifting between Greenland and Rockall, and the subsequent formation of the triple point (Vogt and Avery, 1974; Olivet et al., 1974). Associated volcanism may be indicated by Rohan and Eriador seamounts.

\section{Pre-Oligocene Structure and Stratigraphy - The Transition From Rifting to Spreading}

Evidence that the pre-Oligocene section partly records the transition from rifting to spreading is given by the magnetostratigraphy of Sites 403-406 (Hailwood et al., this volume). At Sites 403 and 404, the entire pre-NP 12 (early Eocene) sequence is reversely magnetized. Comparison with the magnetobiostratigraphic record for nearby Sites 405 and 406 shows that the reverse magnetization was acquired during the long polarity interval preceding anomaly 24. Normal polarity intervals corresponding to anomalies 23 and 24 were detected in the post-NP 12 section at Site 404 . Since the oldest anomalies adjacent to the margin are $24 B, 24$, and $23 A$, the sedimentary record at least partly bridges the transition from rifting to spreading between Greenland and the Rockall Plateau.

These observations are crucial in understanding the seismic stratigraphy and, in turn, the changes in depositional environment, subsidence and tectonics of the Rockall Plateau in pre-Oligocene time. The pre-Oligocene interval is conveniently divided into two seismic units by a widespread strong reflector of late Paleocene age penetrated in Sites 404 and 117 (Figures 7, 9a, 12, 13) and of inferred late Paleocene age at Sites 403 and 406 . The anomaly 24 polarity interval lies within the upper unit of late Paleocene/ late Eocene age. The lower, pre-upper Paleocene unit therefore unequivocally pre-dates the spreading between Greenland and Rockall being deposited contemporaneously with rifting.

\section{The Pre-Upper Paleocene Interval}

The distribution and thickness of the pre-upper Paleocene sediments is highly variable and closely related to basement structure. On the older upper Cretaceous/Paleocene ocean crust south of the fracture zone (Figure 13), the interval is thickest and characterized by strong locally faulted (?) reflectors, with high interval velocities of about 4.0-4.5 $\mathrm{km} / \mathrm{s}$, which appear to diminish southward. As in the Edoras and Hatton-Rockall basins, the top of the pre-upper Paleocene unit is marked by a strong flat-lying reflector. The reflection is associated with a velocity inversion, and its strength implies a high impedance contrast. We suggest this reflection may be caused by extrusives perhaps associated with the onset of spreading between Greenland and Rockall and/or the changes in spreading geometry responsible for the formation of the triple point at $56^{\circ} \mathrm{N}$.

On the Rockall Plateau, the unit cannot be unequivocally mapped and identified because of the variable quality and spacing of the seismic profiles. In the Hatton-Rockall Basin, the strong reflector defining the top of the unit can be correlated with the subaerial lava flow penetrated at Site 117 (Laughton, Berggren, et al., 1972). The reflector is not ubiquitous and, where it is absent, irregular strongly diffracting basement (pre-Cambrian) is present (Figure 9). The reflector is locally underlain by an interval of strong reflections comparable to those observed south of the transform and in the Edoras Basin. In contrast to the post upper Eocene intervals however, it occurs beneath both Hatton Bank and the Hatton-Rockall Basin in fault-bounded basins of variable thickness. The faulting was probably contemporaneous with rifting but continued into late Paleocene/Eocene time as the lower part of this interval is affected by faults (Figure 14).

Along the west margin the pre-Paleocene unit is thickly developed within the northeast-southwest-trending linear basins. With the Edoras Basin (Figure 12) the unit consists of a westward-prograding sediment wedge, locally of deltaic aspect and at least $3.0 \mathrm{~s}$ in thickness. Basement is rarely observed beneath the wedge. The top of the unit is represented by the polymict conglomerate of late Paleocene age drilled at Site 404 (Figure 7). High interval velocities of 3 to $4.5 \mathrm{~km} / \mathrm{s}$ and the nature of the overlying sediments suggest that the unit may comprise interbedded extrusives and clastics. Watts et al. (1975) have dredged arkosic arenites and fossiliferous oolitic limestones of inferred Cretaceous-Paleogene age in 465 to 1170 meters on the northern edge of Hatton Bank; their compressional wave velocities of $4.0-5.9 \mathrm{~km} / \mathrm{s}$ lie within the range of interval velocities observed in the pre-Paleocene sequence. Within the interval, westward-diverging faulted reflectors are strongly indicative of syn-depositional subsidence. These reflectors are faulted, flatten and locally tilt upward against the flanking basement high to the west (Figures 10, 12, 13, 14 [Figure 14 is in back pocket, this volume]). Contemporaneous downfaulting along the margin of the high and on the fault west of Edoras Bank (minimum throw $5 \mathrm{~s}$ ) probably controlled the subsidence in the basin.

On the southwest margin, the pre-Paleocene interval is largely confined to a series of northeast-southwest-trending basins that curve westward to converge with the transform 


\begin{tabular}{|c|c|c|c|c|c|c|c|c|c|c|c|c|}
\hline \multirow[b]{2}{*}{ NW } & \multirow[b]{2}{*}{$\mathfrak{h}_{1} 472314750$} & \multicolumn{2}{|c|}{$\begin{array}{l}\text { LINE IPOD76-6 } \\
\text { SP.14330V }\end{array}$} & \multicolumn{3}{|c|}{$\begin{array}{l}\text { LINE IPOD } 76-5 \\
\text { SP. } 13470\end{array}$} & \multirow[b]{2}{*}{15050} & \multirow[b]{2}{*}{15100} & \multirow[b]{2}{*}{$\checkmark$} & \multirow[b]{2}{*}{$\check{V}_{15200}$} & \multirow[b]{2}{*}{15250} & \multirow[b]{2}{*}{$15299 \mathrm{~s}$} \\
\hline & & $Y 14800$ & $\sqrt{14850}$ & Y & 14950 & $\downarrow 15000$ & & & & & & \\
\hline
\end{tabular}

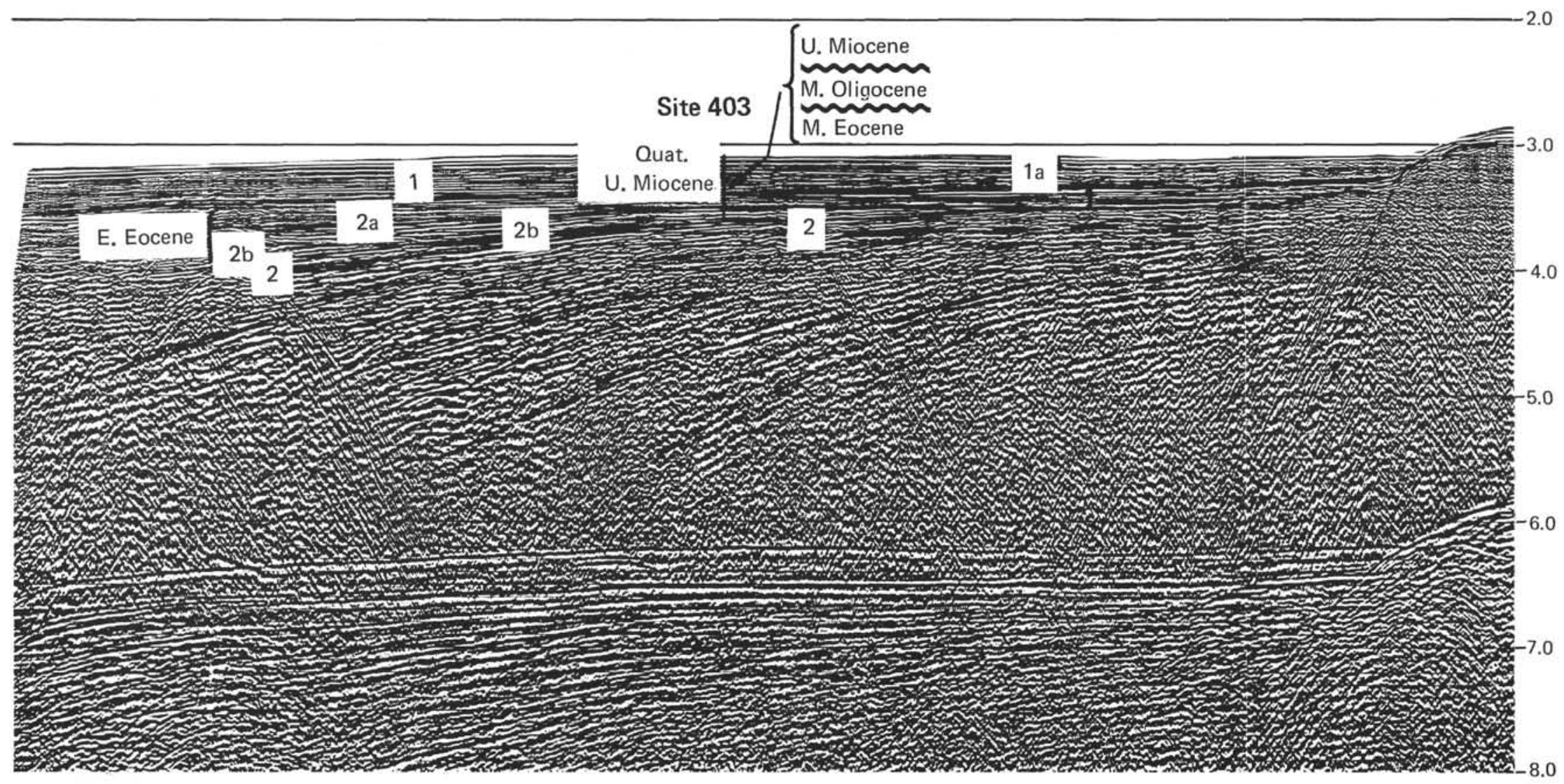

Figure 12. Multichannel seismic reflection profile through DSDP Sites 403 and 404. 


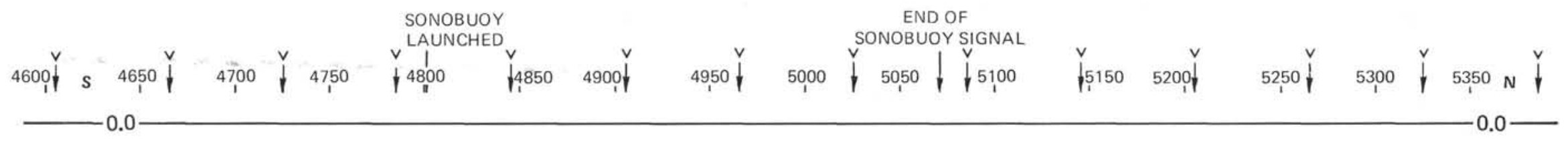

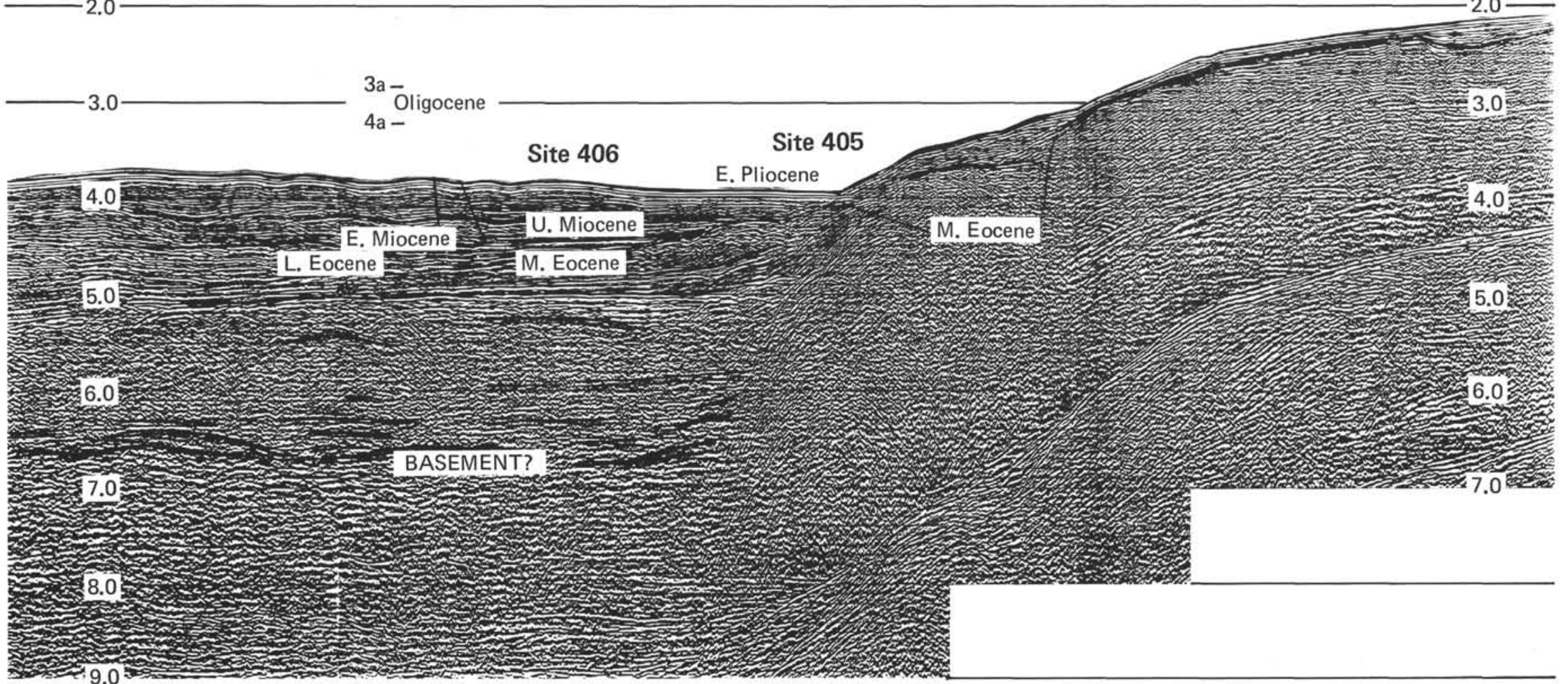

Figure 13. Multichannel seismic reflection profile through DSDP Sites 405 and 406. 
fault plexus (Figure 5). This pattern and the seismic stratigraphy suggest not only that deposition was contemporaneous with rifting, but that rifting was contemporaneous with transcurrent faulting along the fracture zone to the south. The majority of the basins appear to be controlled by normal faults, and lystric faults like those of the Bay of Biscay have not been seen (Montadert et al., this volume; De Charpal et al., in press). Their apparent absence may, however, be due to the limitations of the seismic reflection technique in resolving such faults in the presumed metamorphic basement.

The attitude of the Edoras Basin at the end of the pre-upper Paleocene interval is shown by paleo-isobaths (not corrected for tilt), constructed on the upper Paleocene reflector using paleobathymetric data from Sites 403 and 404 (Montadert, Roberts, et al. [Sites 403/404]; Murray, this volume). The reconstruction shows that the seabed then dipped gently westward from the beach at the foot of Edoras Bank to depths of as much as 700 meters adjacent to the flanking outer basement high (Figures 15, 16). Edoras Bank evidently had a substantial subaerial relief of about 1400 meters which may well have been exceeded on the shallower Hatton Bank. The northward decrease in depth of the outer high suggests that this feature comprised a prominent flat-topped shoal that may have been subaerial (Figure 14a). The depth of deposition of less than 100 meters in late Paleocene time at Site 117 in the HattonRockall Basin also indicates that Rockall Bank was subaerial (Laughton, Berggren, et al., 1972). However, the present depths of the upper Paleocene at Sites 404 and 117 of 2800 and 1350 meters indicate subsequent subsidence to these depths and relative movement of about 1500 meters.

\section{The Upper Paleocene-Pre-Oligocene Interval}

In contrast to the underlying unit, this interval is characterized by the absence of strong reflectors and is thus easily identifiable on seismic profiles.

Above the Upper Cretaceous/Paleocene ocean crust, the interval consists of upper Paleocene/middle Eocene sediments that comprise a prominent sediment wedge abutting the foot of the transform scarp (Figure 13) The wedge thins southward and is characterized by the absence of strong reflectors. Sedimentation rates of $70 \mathrm{~m} / \mathrm{m} . \mathrm{y} .^{-9}$ contrast with rates of $250 \mathrm{~m} / \mathrm{m}$.y. estimated for the underlying interval.

In the Hatton-Rockall Basin, the unit is of late Paleocene to late Eocene age and is again characterized by the absence of strong reflectors. It is thickest $(\sim 0.4 \mathrm{~s}$ two-way time) within the basin and is absent on Rockall Bank and Hatton Bank where it is overlapped by the post-upper Eocene sequence (Figure 14B, back pocket, this volume). The upper part of the interval penetrated at Site 116 consisted of limestones of upper Eocene age deposited in 600 meters depth (Figure 7). The lower part of the interval penetrated at Site 117 on the flank of the basin consisted of shallow water upper Paleocene-lower Eocene beds overlapped by Oligocene beds. Lithologic and paleontologic studies indicate subsidence from subaerial/littoral depths to depths of between 500 and 800 meters by early Eocene time (Laughton, Berggren, et al., 1972). Seismic profiles across the Hatton-Rockall Basin suggest that the lower part of the unit was affected by faulting (Figure 14B).
Within the Edoras Basin, the unit is of late Paleocene/middle Eocene age and is unconformably overlain by middle Oligocene beds (Site 403) and upper Miocene beds (Site 404) (Figure 7). The unit contains few reflectors and consists of intercalated volcaniclastics, sandstones, and mudstones deposited in a basin, the depth and geometry of which varied greatly between late Paleocene and Eocene time (Figure 17). Faulting of only the lower part of the interval has been observed only adjacent to the outer high (Figure 12). Depths varied from very near shore in late Paleocene time to about 75 meters by anomaly 24 time at Site 404 and, at Site 403 , from mid inner shelf to less than 10 meters and to 100 meters by middle Eocene time (Murray, this volume).

Sediments deposited in the long reversed polarity interval preceding anomaly 24 were derived from the northwest (Hailwood and Sayre, this volume) either from the flanking basement high or the partly juxtaposed East Greenland margin. However, isopachs on the interval between reflectors $1 \mathrm{~A}$ and $2 \mathrm{~A}$ (lower Eocene) show evidence of northeast-southwest-trending depocenters exhibiting northeastward prograding reflectors (Figure 18). Subaerial erosion is also indicated by heavy mineral assemblages consisting of high-grade metamorphic minerals (Harrison et al., this volume). The changes in depth and relative relief between Sites 403 and 404 (Murray, this volume) may reflect migration of the depocenters within the basin.

Contemporaneous and perhaps local volcanism is evidenced by abundant tuffaceous horizons and high thermal indexes (Harrison, et al., this volume; Costa and Downie, this volume). The main tuffs at Site 403 are of NP 10 age and occur in the reversed polarity interval preceding anomaly 24 . More widespread volcanism of obvious tectonic importance is indicated by the occurrence of contemporaneous tuffs in the North Sea Basin (Jacque and Thouvenin, 1975).

Shortly after anomaly 24 time, the Edoras Basin began to subside rapidly and there was a marked decrease in volcanism recorded as a sharp drop in tuffaceous material. At Site 403 , depths changed from less than 10 meters to more than 100 meters and a comparable change is also present at Sites 404 and 117 (Figure 19). It should again be noted that depths of Sites 403, 404, and 117 were comparable through late Paleocene-middle Eocene time. The present difference in depth of 1500 meters between these sites can only be ascribed to subsequent relative movement and subsidence of about 1500 meters possibly related to varying crustal thickness or distance from the spreading center.

\section{Tectonics of Rifting and Spreading}

There is a clear and obvious correlation between the geological history of these sites and the transition from rifting to spreading. The margins of the southwest Rockall Plateau were shaped by rifting and transform faulting that may have been at least partly contemporaneous. The preceding discussion of the pre-Oligocene geological history offers a useful preface for a more detailed examination of the history of vertical movements along transform faults and the transition from rifting to spreading. 


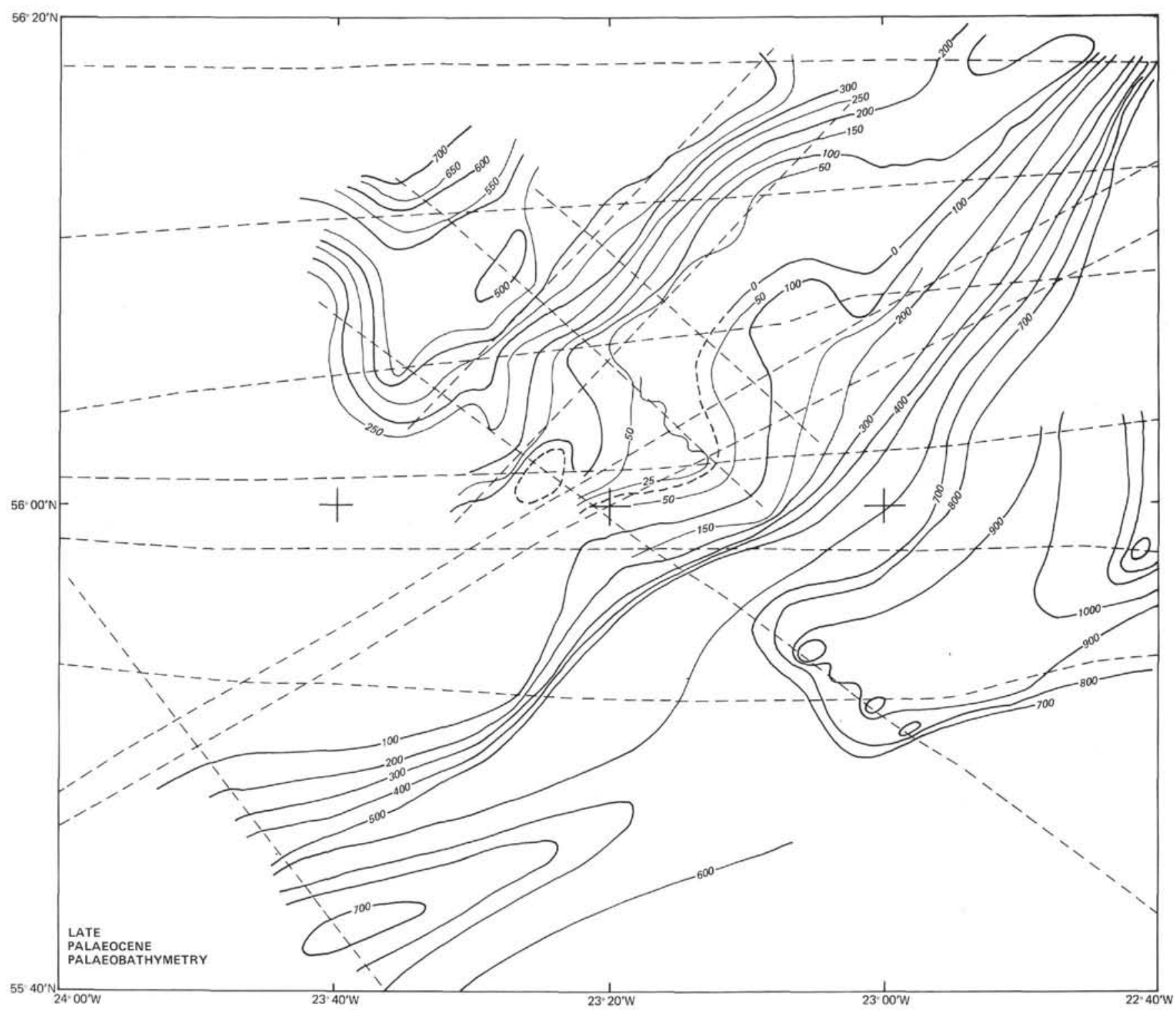

Figure 15. Late Paleocene paleobathymetry of Sites 403 and 404. Paleobathymetry has been derived from paleodepths (Murray, this volume) and depths to the late Paleocene reflector and basement obtained from interval velocity data.

\section{Development of the Transform Boundary}

South of Edoras Bank, the oldest sediments comprise an interval of strong flat-lying reflectors that infill the irregular oceanic basement of inferred Late Cretaceous/Paleocene age. The 4 to $5 \mathrm{~km}$ thick sediments between the upper Paleocene reflector and the oceanic basement were deposited entirely between Late Cretaceous and late Paleocene time. These sediments, deposited on ocean crust accreting south of the transform fault, are at least partly contemporaneous with those deposited at Sites 403 and 404 in the rifting basin on continental crust. During middle Eocene time, epibathyl depths existed at Sites 405 and 406. The difference in depths between Sites 403 and 404, and Sites 405 and 406 was thus about 1000 meters, close to the present difference in levels between the middle Eocene reflector at these sites (2561 and 3681 meters, respectively).
The absence of any post-middle Eocene displacement between these sites and the existence of epibathyal depths imposes several constraints on the history of vertical movements along the scarp that may be of more general application. Since the post-middle Eocene section is apparently not faulted, it is clear that a large part of the scarp must have been subaerial in middle Eocene time. The seismic profile and the epibathyal depths suggest a total relief of $2.6 \mathrm{~km}$ of which at least $1.6 \mathrm{~km}$ were sub-aerial (a figure independently supported by the Site 403/404 data; see Figure 17). Since middle Eocene time, the continental and oceanic crust on either side of the transform have remained coupled and have subsided to their present depths. The seismic data show a further $1.8 \mathrm{~s}$ of relief (between 4 and 5 $\mathrm{km}$ ) below the upper Paleocene reflector. Because the post-upper Paleocene sequence is not faulted, a relief of about 6.5 to $7.5 \mathrm{~km}$ along the fault was created by middle Eocene time. Further, because the transform fault was 
SE NW $+1500 \mathrm{~m}$
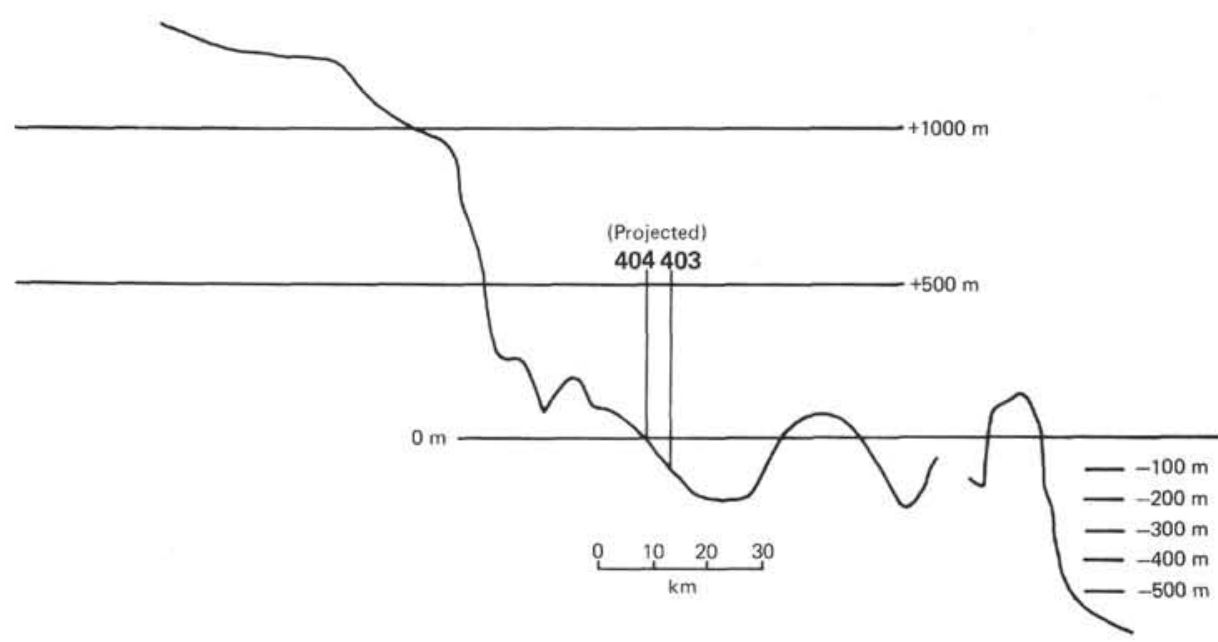

Figure 16. Late Paleocene paleobathymetric profile through DSDP Sites 403/404 and Edoras Bank.

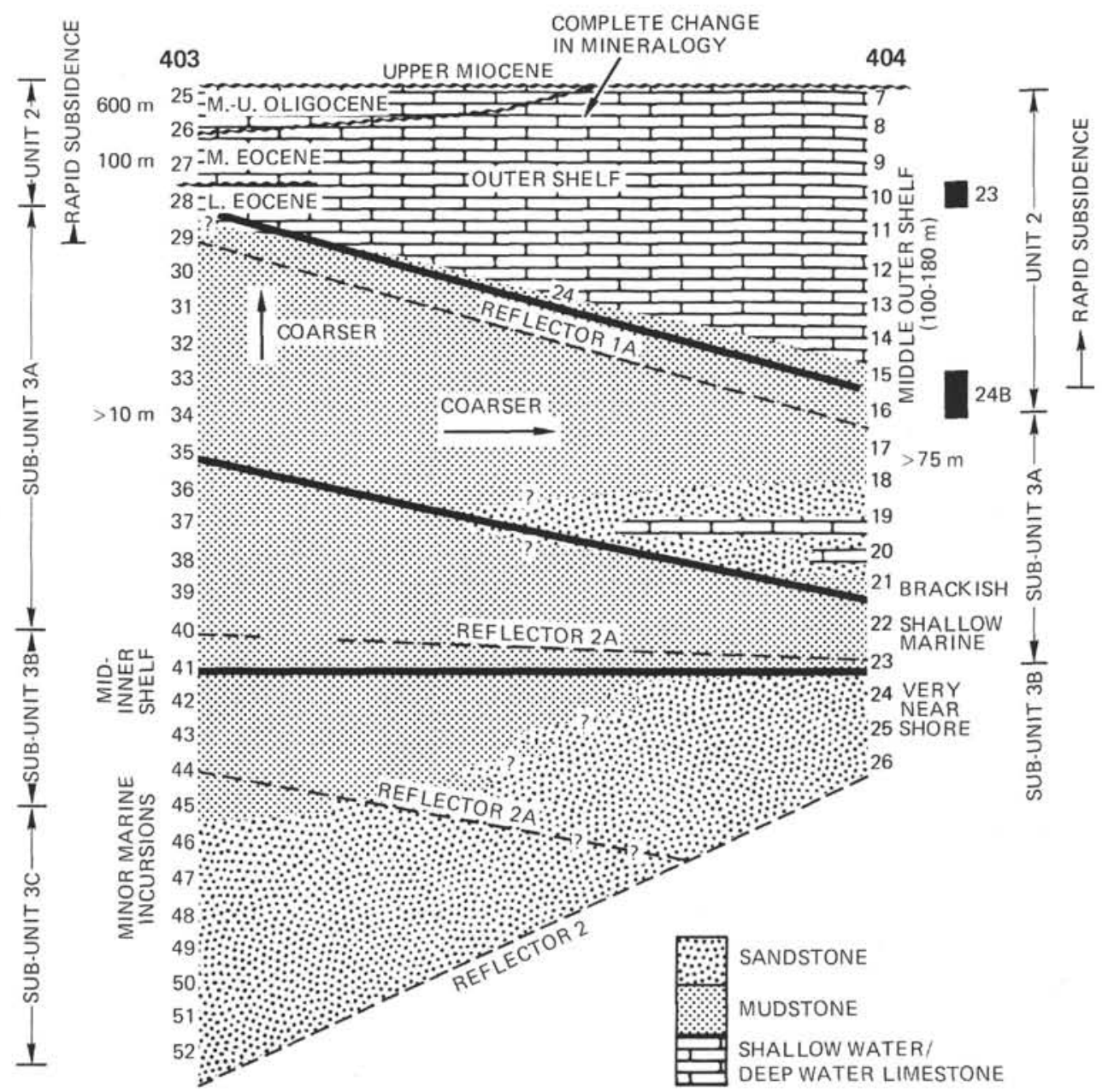

Figure 17. Facies relationships between Sites 403 and 404 showing principal lithologies, paleodepths, and magnetic reversals at Site 404. Lower Eocene of Site 403 was entirely of reverse magnetization. 


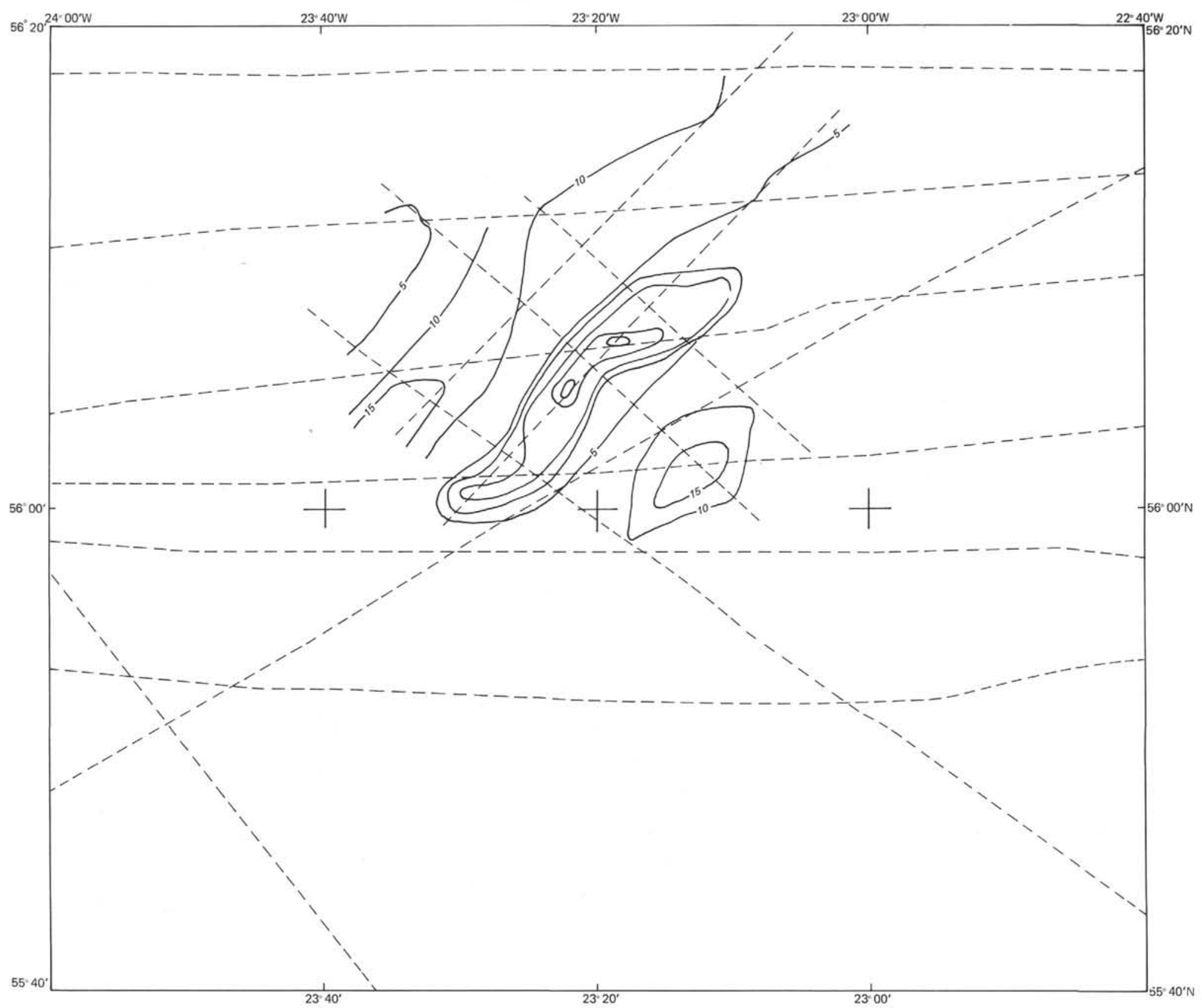

Figure 18. Isopachs on the interval between reflectors $2 A$ and $1 A$ in the Edoras Basin. Contours in milliseconds $\times 10$. 


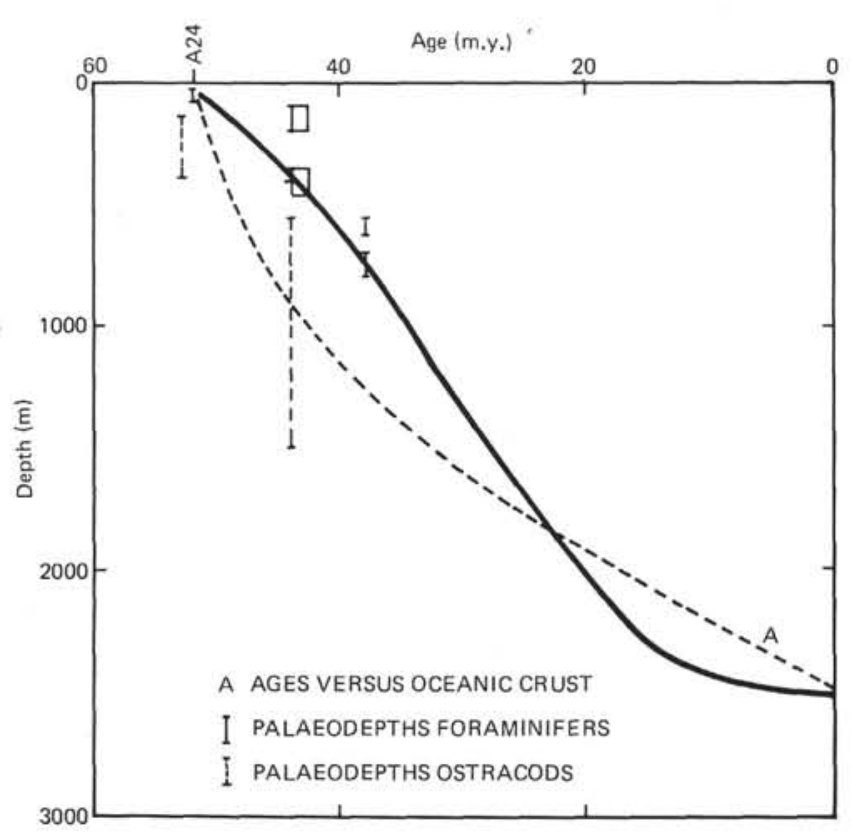

Figure 19. Subsidence history of Sites 403-404 (based on paleodepths given by Murray (this volume) and Ducasse and Peypouquet (this volume)).

formed in the Late Cretaceous (anomaly 31-32 time) and remained active until $52 \mathrm{~m} . \mathrm{y}$, when the spreading axis passed beyond the trailing edges of the continents, it is inferred that vertical decoupling of the continent/ocean boundary in addition to horizontal decoupling took place along the transform. This relief however may have developed during both the rifting and the spreading processes.

Present-day transform fault offsets can be regarded as marking offsets in the axis of rifting unless migration has taken place. The junction between the incipient transform and the rift thus marks a major change in tectonic regime from transcurrent to normal faulting (Figure 20). In particular, the rifting is revealed by down to basin normal faulting. Crustal extension and thinning are produced by a combination of brittle fracture in the upper crust and ductile flow below. The relief between the continental crust (transform offset) north of the transform and the adjacent rifted continental crust to the north, decreases eastward towards the continent, but is greatest at the continent-ocean boundary. This observation suggests that much of the vertical relief of the transform is produced before spreading, by downfaulting of the rifting continental crust against the incipient transform fault, perhaps leading to the development of hinge lines characterized by complex crossfaulting.

Juxtaposition of transform and rifted margins poses several questions concerning mechanisms of deformation in the lower part of the crust. The continent adjacent to the transform has a thickness of between 20 and $30 \mathrm{~km}$ whereas, at the adjacent rifted continent/ocean boundary, the thickness may be only about $12 \mathrm{~km}$. Beneath the outer part of rifted margins, the depth of the brittle-ductile flow boundary is considered to lie at or just above the Moho (Montadert, Roberts, et al., this volume). In contrast, along transforms in continental crust this boundary is considered to lie deeper at $\sim 15 \mathrm{~km}$ based on the depth distribution of earthquakes.

Speculatively, the depth and indeed the nature of this boundary may clearly change both parallel and perpendicular to the transform during rifting and spreading (Figure 20). During rifting, horizontal shear takes place between thick and thinning continental crust. In contrast, during spreading, the shear takes place, not only between thick and thinned continental crust, but also between thick continental and thin accreting ocean crust. The continent may also be heated as it slides past the spreading center. The implications of these inferences for the tectonic history of transforms cannot be assessed from the data available, nor can the effects of sediment loading during this interval. Nonetheless, the Leg 48 results show that the continental and oceanic crust have remained coupled across the transform and have jointly subsided to their present depths since the separation of the trailing edges of the continents at about 52 m.y.

\section{Initiation of Sea-Floor Spreading}

Along the margin formed by rifting between Greenland and Rockall, the seismic, magnetic, and deep-sea drilling data document the timing of the transition from rifting to spreading and constrain the conditions of formation of the new oceanic crust. The multichannel profile of Figure 10 crosses from the continental slope onto the oceanic crust and passes through Sites 403 and 404. No sharp change in seismic character that might correspond to the continent/ocean boundary is obvious on the profile. On the evidence of the position of the reversal preceding anomaly 24 the boundary is inferred to lie at the outer edge of the high, observed between shot points 1200 and 1600. The prominent reflector, E, arises from a lower Eocene tuff penetrated at Site 403 and deposited towards the end of the reversed polarity interval preceding anomaly 24 . Reflector E crosses the continent/ocean boundary and merges with a strong flat-lying reflector originally considered to be the top of the oceanic basement. Beneath this "basement" (Figure 10), however, many discontinuous dipping reflectors are present that are observed at least as far west as anomaly 22 . In view of the age of reflector $E$ and the magnetic anomalies, these reflectors and the "basement" are clearly diachronous. Closely comparable reflectors have also been observed in the Lofoten Basin and west of the Vøring Plateau (Hinz, personal communication).

The oldest magnetic anomaly adjacent to the margin in the south is the negative anomaly formed during the reverse polarity interval preceding anomaly 24 . Further north, however, anomaly 24 , then $23 A$ and again 24 are successively juxtaposed against the margin (Figure 11a). These observations suggest the transition from rifting to spreading began before anomaly 24 time, but may have been associated with a minor shift of the spreading axis between $56^{\circ} \mathrm{N}$ and $58^{\circ} \mathrm{N}$. Changes in the lithology and depth of deposition recorded at Sites 403 and 404 during Paleocene/Eocene time were most probably caused by the transition from rifting to spreading. The strong upper Paleocene reflector defines a major lithological break coincident with a marked decrease in faulting. This event (Figure 17) occurred during the early part of the reversed 


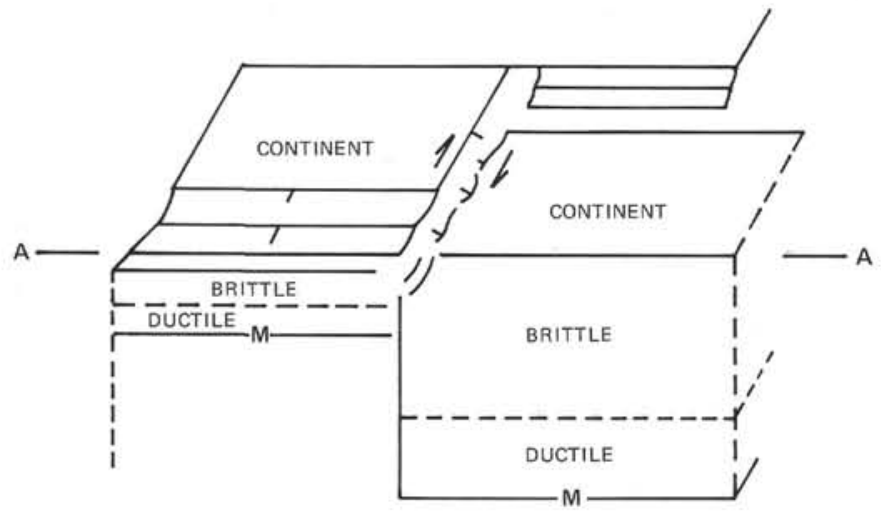

arity interval preceding anomaly 24 . The overlying reflector E of early Eocene age occurs, however, within the upper part of this reversed polarity interval and also merges with the "basement" of the oceanic crust formed during this polarity interval. In view of these data and the absence of anomaly 25 adjacent to the plateau, the upper Paleocene reflector is considered to mark the initiation of the transition from rifting to spreading. The transition from rifting to spreading probably involved the formation of a sinuous split and local migration of the spreading axis. Evidence for this is given by the continuity of anomaly 24 off east Greenland in contrast to its discontinuity west of Rockall Plateau, and the asymmetry of anomalies 22 to 24 north of Hatton Bank (Roberts, 1975; Bott et al., 1977).

The transition from rifting to spreading was clearly completed by anomaly 24 time. The magnetostratigraphy of Sites 403 and 404 suggests that the transition could not have taken more than 3.2 m.y., whereas sedimentation rates suggest it may have taken as little as $2 \mathrm{~m}$.y. The first accretion of ocean crust may be recorded by the eruptive phase that took place in NP 10 time and which is clearly regional in importance in view of its occurrence in the North Sea (Harrison et al., this volume; Jacque and Thouvenin, 1975). Completion of the transition from rifting to spreading may be recorded by the rapid subsidence of Site 404 that began during anomaly 24 time ( 52 m.y., Hailwood et al., this volume). The absence of an appreciable change in sedimentation rate suggests the subsidence was initiated spreading.
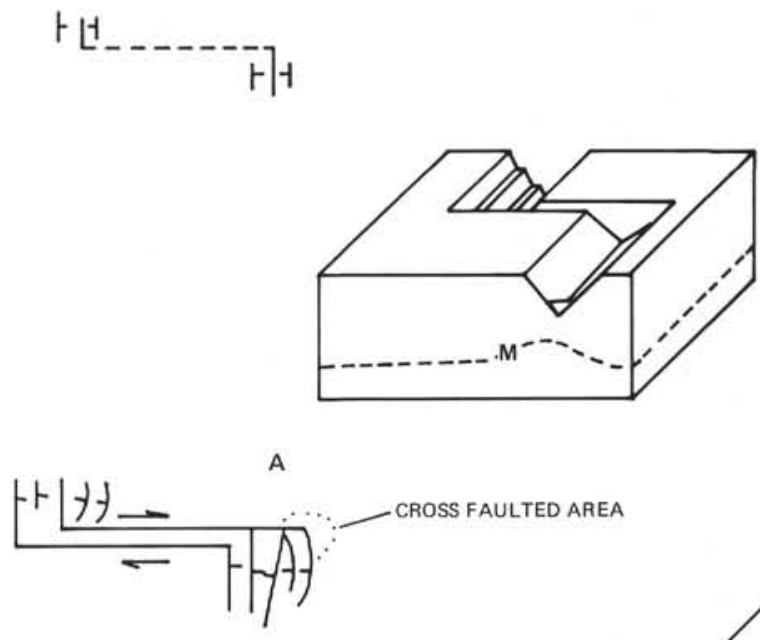

A

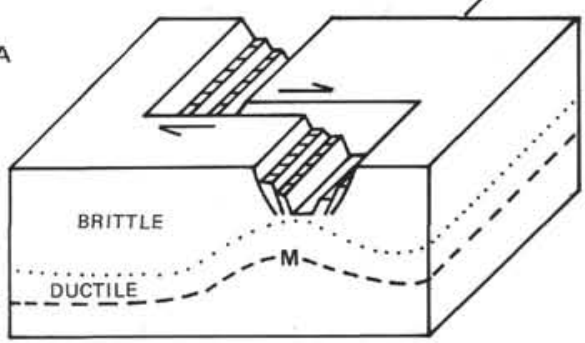

VERTICAL DISPLACEMENT ALONG TRANSFORM MAY DEVELOP PRIOR TO SPREADING

Figure 20. Hypothetical structural sketches of the evolution of transform margins during the transition from rifting to

by cooling associated with the change in thermal regime and/or changes in crustal thickness and density consequent on the transition from rifting to spreading. Initiation of the subsidence during anomaly 24 time suggests an unconformity with the evidence presented above, that the transition was completed by anomaly 24 time (Figure 21 ).

The paleodepths of Sites 403 and 404 (Figure 17) are of considerable significance in inferring the depth and thus the environment in which spreading first began. The lower Eocene tuff causing reflector $\mathrm{E}$ was deposited in depths of less than 100 meters (Murray, this volume). The present difference in altitude of 750 meters between reflector $\mathrm{E}$ at Site 403 and on the adjacent oceanic crust indicates accretion of the first oceanic crust in depths of 850 meters or less (Figure 10). This depth should be regarded as a maximum since a correction for subsequent tilt of unknown magnitude cannot be made. The basement high at the continent/ocean boundary may have been in shallow depths or even locally subaerial. Contemporaneous sedimentation rates were extremely high and were at least $71 \mathrm{~m} / \mathrm{m} . \mathrm{y}$.

The first oceanic crust thus accreted contemporaneously with rapid sedimentation in shallow water depths. The layered structure (Figure 10) of the "oceanic" basement can be most easily attributed to the interbedding of lava flows and sediments that would occur under these conditions. The strength of the "basement" reflection and a velocity inversion suggest it may arise from extrusives. Refraction velocities for the oceanic basement are low at $3.8 \mathrm{~km} / \mathrm{s}$, (cf. 

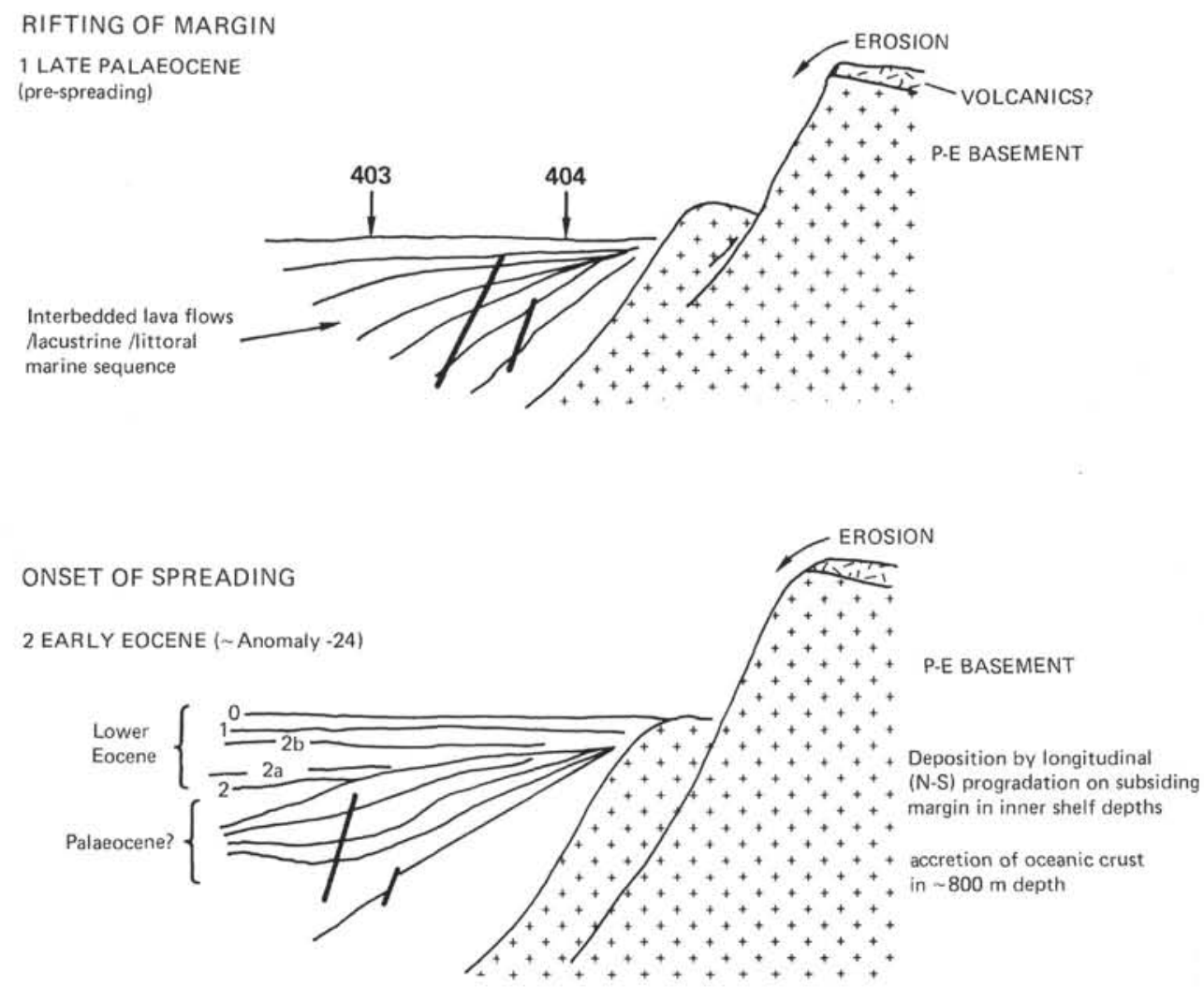

3 MIDDLE EOCENE

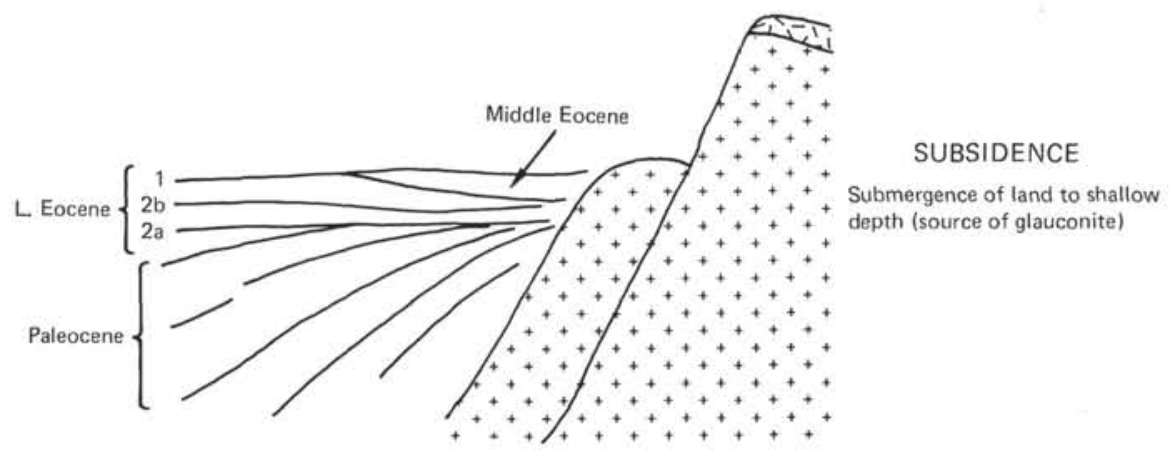

Figure 21. Schematic evolution of the western margin of the Rockall Plateau.

average oceanic crustal velocities of 4.0 to $6.0 \mathrm{~km} / \mathrm{s}$, Schreiber and Fox, 1973) and interval velocities are $\sim 3$ to $3.5 \mathrm{~km} / \mathrm{s}$.

The flat-lying character of reflector $\mathrm{E}$ and the underlying discontinuous reflectors is maintained as far west as anomaly 21-22, where the basement shoals and becomes more irregular and more typical of mid-ocean ridge topography. To the north, however, the basement rises towards the flank of the Iceland-Faeroes Ridge which was subaerial in Eocene time (Talwani, Udintsev, et al., 1977). The depth of the Iceland Basin therefore decreased northward to become subaerial on the flanks of the Iceland-Faeroes Ridge. The flat-lying character of the "basement'" may be due to lava flows voluminously erupted due to proximity to the Iceland-Faeroes hot spot or perhaps the nearby triple point. The reason for the change in basement character at anomaly $21-22$ is less obvious. If its flat-lying nature is indeed due to voluminous lava flows, then the change may reflect a decrease in eruptive activity associated with the terminal development of the Iceland-Faeroes Ridge.

Some remarks on the depth of the oceanic crust and its subsidence history are of relevance to the early development of spreading basins.

The present depth of the oceanic crust adjacent to the margin is 3450 meters, or 3233 meters after making an isostatic correction for an estimated sediment thickness of 400 meters. This is substantially shallower (Figure 22) than the depth of 5500 meters predicted from the average age versus depth relationship for mid-ocean ridges (Le Pichon et 


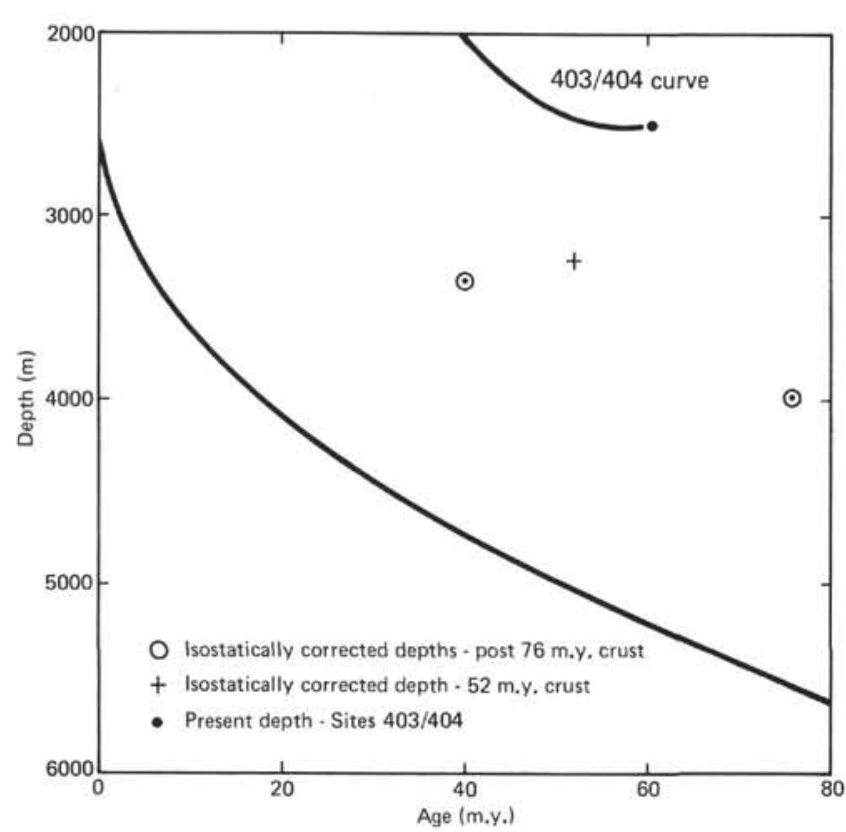

Figure 22. Intercomparison of isostatically corrected depths to the oceanic basement adjacent to the 52- and 76-m.y. margins of the Rockall Plateau and the age versus depth curve for the ocean crust of Le Pichon et al. (1977). Part of the subsidence curve for Sites 403/404 (Figure 19) is also shown.

al., 1977). However, the present depth of the Reykjanes Ridge crest is about 1000 meters compared to the world average of 2600 meters. Fitting of theoretical cooling curves (Sclater et al., 1971) gives a good fit to the observed topography of the ridge flanks; the difference in depth is most easily explicable by a thinner and hotter lithosphere (Haigh, 1975). Veevers (1977) has postulated that the depth of the mid-ocean ridge crest is a function of the age of the ocean basin. Our data do not support his conclusion but hint that proximity to a hot spot or triple point may have been perhaps important.

We have also investigated sea-floor subsidence near the older margin to the south, where a constraint on the depth of the ocean basin is provided by the inferred epibathyal conditions in middle Eocene time (Figure 22). The depth of the middle Eocene reflection at Site 406 is 3723 meters (water depth 2967 meters) and $4.0 \mathrm{~km}$ on Line IPOD 76-1 at a depth of 2670 meters below sea level. These figures give isostatically corrected depths of 3373 meters for Site 406 and 3420 meters on IPOD 76-1. Subsidence of $\sim 2500$ meters has taken place between the middle Eocene and the present. Isostatic correction of the oceanic basement depth adjacent to the rifted margin indicates a depth of about 4000 meters. These depths are plotted on Figure 22 and again lie considerably above the age versus depth curve for the mid-ocean ridge. The shallow depths imply that the $76 \mathrm{~m}$.y. crust first formed in shallow depths, a conclusion independently supported by the erosion surface observed close to the continent/ocean boundary on Profile IPOD 76-1 (Figure 23, back pocket, this volume).

At this latitude $\left(53^{\circ} \mathrm{N}\right)$, the average depth of the Mid-Atlantic Ridge is considerably deeper than the Reykjanes Ridge, but closer to the world average of 2600 meters. The cause of the difference is not certain, but it is suggested that a substantial change in the temperature and thickness of the lithosphere took place between middle Eocene time and present. It might also be related to the end of the triple point near anomaly 21-22 time. In all cases however, the cooling curves imply that early accretion of ocean crust and contemporaneous sedimentation took place in shallow water conditions.

\section{Post-Rift Subsidence}

The transition from rifting to spreading marks a major change in the tectonic and sedimentary regimes of the Rockall Plateau and its margins. All sites underwent rapid subsidence in Eocene time so that the depositional environment changed from shallow water marine to deep water marine (Montadert, Roberts, et al., 1977). In this section, we discuss the comparative subsidence histories of the DSDP sites and their implications.

Subsidence curves for the Paleocene at the various DSDP sites (Figure 24) are based on paleontologically derived water depths (Murray, this volume; Ducasse and Peypouquet, this volume; Benson et al. in Laughton, Berggren et al., 1972) isostatically corrected for sediment loading (Figures 2, 3). In the case of Site 116, where the Paleocene was not penetrated, "basement" has been assumed to be of Paleocene age because of its similarity and seismic correlation with the basement cored at Site 117. Paleodepths for the basement have there been derived by isostatically correcting the sediment load for each epoch for which paleobathymetric data were available.

At Sites 403 and 404, water depths changed from less than 100 meters at the onset of spreading (early Eocene) to more than 600 meters by Oligocene time (Murray, this volume; Ducasse and Peypouquet, this volume). Rapid subsidence from littoral to bathyal depths during early Eocene time was also recorded at DSDP Sites 116 and 117

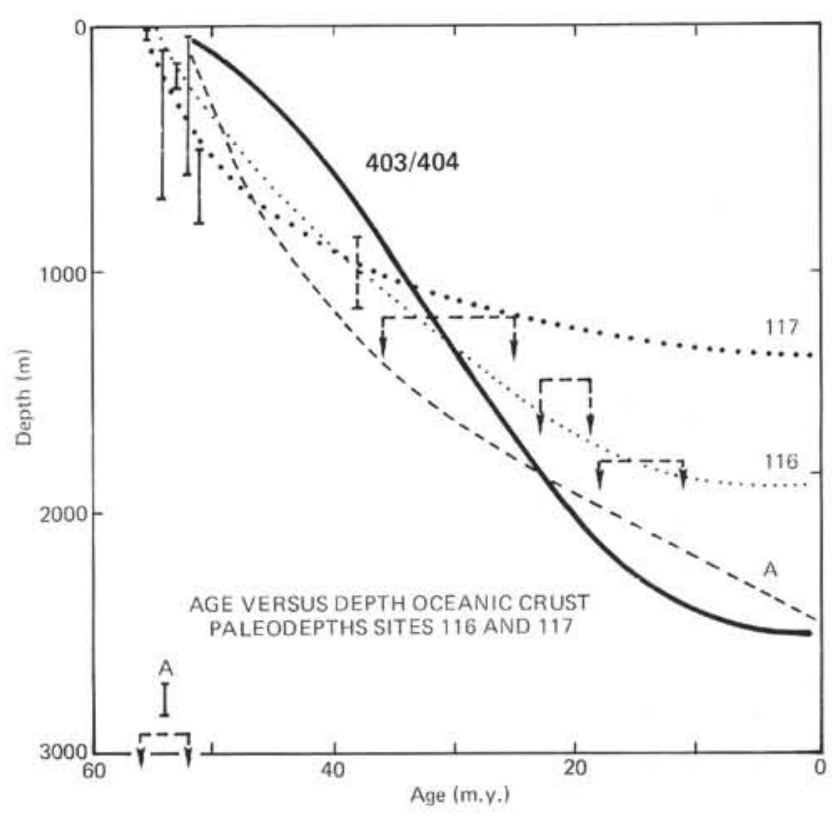

Figure 24. Comparative subsidence curves for DSDP Sites $403,404,116$, and 117. 
(Laughton, Berggren, et al., 1972). Extrapolation of the curve for Site 116 backwards in time suggests that the site lay at, or close to, sea level in late Paleocene-early Eocene time which is in agreement with the comparable shallow depths of Sites $403 / 404$ and 117 at that time. The close similarity in depth supports the earlier inference that the present relative altitudes of the sites, and indeed the "basin-high"' morphology of Rockall Plateau, owes much to post-rifting differential subsidence.

The greatest subsidence (Figure 24) is observed at Sites $403 / 404$ adjacent to the continent/ocean boundary and situated on substantially thinned continental crust (Figures 2,24 ) and the least is at Site 117 on the thickest crust of Rockall Bank, furthest from the continent/ocean boundary formed at $52 \mathrm{~m} . \mathrm{y}$. Subsidence in the Hatton-Rockall Basin, situated at an intermediate distance and on crust of intermediate thickness, lies between these amounts (Figure 24). The curves suggest that subsidence ended earlier at sites situated most distant from the continent/ocean boundary and on the thickest crust. Subsidence may also have ceased early at some sites situated adjacent to the continent/ocean boundary. In contrast, the site situated on the thinned crust of the Hatton-Rockall Basin continued to subside until Miocene time, perhaps indicating a greater thermal anomaly in the basin due to rifting. Thus the Hatton-Rockall Basin was shaped by differential subsidence shown as down-warping along lines structured during rifting.

The curves can also be used to infer the age of submergence of the adjacent shallow banks and thus the date at which the supply of clastic sediments was cut off. If it is assumed that the subsidence curves for the thickest crusts are the same (neglecting unknown variations in temperature), the present depth of the Hatton Bank can be backtracked to determine the date of submergence (Figure 25 ). It could be argued that this procedure is meaningless in

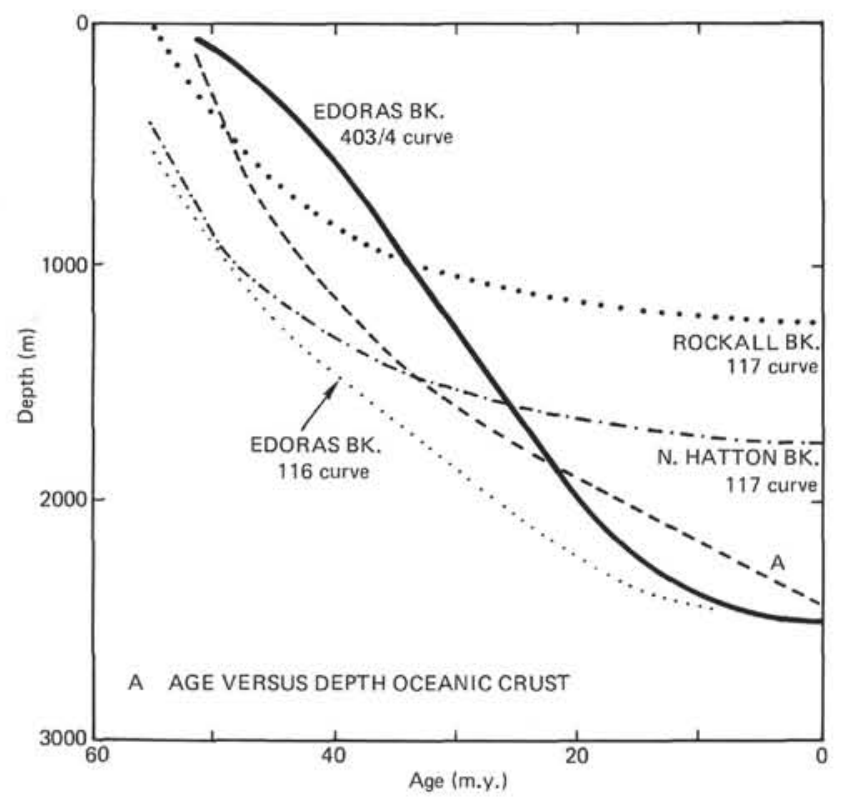

Figure 25. Subsidence curves for Edoras Bank, Halton Bank, and Rockall Bank using subsidence criteria discussed in text and curves given in Figure 24. view of these assumptions and the crudity of the paleobathymetric data. Nonetheless, if tested and supported by independent geological criteria, it may have more general value and application. It may be of relevance to note that Detrick et al. (1977) show that aseismic ridges with very different crustal structure from the normal ocean basins also parallel the standard age/depth curve. Crustal thicknesses beneath north Hatton Bank are most comparable to those beneath Rockall Bank. Backtracking suggests that the present most elevated parts of Rockall Bank may have been at least 1100 meters above sea level in late Paleocene time while the deeper Hatton Bank was at least 800 meters above sea level (Figure 25). Based on the subsidence curve for Sites 403/404, Edoras Bank is inferred to have been at about 1000 meters above sea level in late Paleocene time, a conclusion independently supported by the inferred paleorelief of +1100 meters in late Paleocene time. The flat-topped surfaces of the banks are probably due to erosion during submergence (Figure 23). The crude curves also suggest that the Rockall Plateau, with the exception of the more elevated parts of Rockall Bank, was largely submerged by Oligocene time. This conclusion is supported by the sharp cut off in clastics between middle Eocene and Oligocene time at Sites 403/404 and 117.

It follows from the above that the present elevations should not be used to assess subsidence quantitatively, for we have shown that the amount of subsidence is not correlatable with present altitude. The present morphology may be largely a consequence of differential subsidence reflecting crustal thickness variations and/or distance from the continent/ocean boundary ( $\mathrm{cf}$. Montadert et al., this volume). Finally, it is important to emphasize the marked absence of faulting produced by differential movements of 1500 meters.

\section{Post-Eocene Stratigraphy}

The boundary between the post-Eocene and preOligocene section is approximately defined by a prominent reflector called R4, marking an unconformity of regional extent (Roberts, 1975). The duration of the hiatus is variable, ranging between late Eocene and middle Oligocene time at Site 406, middle Eocene to late Miocene at Sites 404 and 405 , middle Eocene to Oligocene at Site 403 , and from early Eocene to Oligocene at Site 117. The unconformity has clearly been caused by non-deposition and/or erosion (Roberts, 1975; Site Chapters 403/404, 406, this volume). On seismic profiles (Figure 2) R4 is typically a discrete sub-horizontal reflector which may often be masked by diffractions originating within the overlying cherts or diatomites. Within the basinal areas, the Eocene and Oligocene beds are largely conformable, although an important disconformity is developed at the top of the cherts. We include here some remarks on the upper Eocene only penetrated at Sites 406 and 117. At Site 406, the upper Eocene consists of siliceous chalks, diatomaceous chalks, and calcareous chalks, affected by slumping and resting unconformably on the prominent sediment wedge of middle Eocene age that abuts the fault scarp. Upper Eocene beds cored at Site 116 comprised foraminifer nannofossil chalks.

The post-Eocene sediments are thickest in the Hatton-Rockall Basin and adjacent sub-basins, but are thin or absent on the elevated Rockall Bank, Fangorn Bank, 
Edoras Bank, and Hatton Bank. The subcrop of R4 bears a close relationship to the basinal structure (Figures 5, 8) discussed earlier, so that on the margins of the basins, R4 is overlapped by the overlying sediments. Reduced sediment thicknesses on the flat-topped basement highs may be due to later submergence of these features and the winnowing effects of bottom currents.

The post-Eocene sequence can be divided into two seismic units neither of which is everywhere present. The lower unit is characterized by a series of strong reflectors that are laterally irregular and give rise to strong diffractions locally masking the underlying reflector R4. The top of the unit is probably middle Miocene in age and may be a prominent disconformity. A hiatus is present in the lower Miocene but cannot be correlated on a regional basis.

The strong reflectors within the lower unit arise from diatomites of Oligocene and Miocene age. The abundance of diatomites may indicate upwelling against the scarp. Siliceous chalks are also present in the Oligocene-lower Miocene interval at Site 116 and in the Oligocene at Site 404 , indicating that oceanographic conditions then favored high silica production. Deposition of the unit was preceded by a period of erosion or non-deposition responsible for the absence of much of the Oligocene at many sites. The erosion and or non-deposition evidently continued (Figure 7 ), as the early and middle Miocene are also absent at several sites (e.g., Sites 403, 404, and 405).

The top of the lower unit is shown on seismic records as a disconformity also marked by a sharp change in seismic character. The strong reflectors disappear and remain absent in the overlying sequence that continues up to the sea bed. However, the presence of weak wave-like reflectors disconformable to both the seabed and the underlying strongly reflective unit occurs. The change in seismic character is due to a change in both depositional regime and lithological character. A sharp decrease in silica occurs above this level, the overlying beds being predominantly calcareous and sometimes characterized by fine parallel wavy and contorted laminae. The disconformity is considered to occur at about $16 \mathrm{~m}$.y. and may be most plausibly related to the overflow of water across the Iceland-Faeroes Ridge (Vogt, 1972; Roberts, 1975; Talwani, Udintsev, et al., 1977; Thiede, in press). The increase in sedimentation rates in post-middle Miocene time may reflect deposition from the increased suspended load following this event.

The pattern of post-Eocene sedimentation on the Rockall Plateau can be mostly easily understood in terms of a simple model of margin subsidence on which the effects of changing ocean circulation were superimposed. During Oligocene time, continuing subsidence of the Rockall Plateau resulted in submergence of much of the plateau and a change to pelagic sedimentation. At Sites 403 and 404, siliceous chalks were deposited in 600 meters depth in Oligocene time (Figure 17). Although the Oligocene/ Miocene record is fragmentary, continuing subsidence may be inferred for the sites to reach their present depths by late Miocene time.

The fragmentary Oligocene-Miocene record may be due to several factors. The Eocene/Oligocene boundary is associated with erosion and/or non-deposition arising from a change in ocean circulation caused by global cooling and marked by the development of the psychrosphere. It is evident that this event must have affected much of the water column because the Eocene/Oligocene hiatus occurs in sites at different paleodepths (cf. Sites 403, 406, and 117). Continuing subsidence through early and middle Miocene time may have brought the shallower sites into the more vigorous bottom water flow regime developed as a result of overflow across the Iceland-Faeroes Ridge. By this time, submergence of virtually the entire plateau had taken place, completely cutting off any terrigenous sediment supply. The distribution of post-middle Miocene sediments bears a close similarity to the present circulation and sedimentation pattern of the North Atlantic (Jones et al., 1970; Johnson et al., 1971; Roberts, 1975) suggesting the prevalence of a bottom current regime similar in intensity though not necessarily in pattern to that observed today. The data also suggest (e.g., at Site 405) that the currents initiated during Eocene/Oligocene time have persisted (perhaps intermittently) resulting in the development of the longer hiatuses. Oceanographic conditions may well have been more complex in the Pleistocene because cyclic variations in lithology and paleotemperature are evident (Lumsden et al., this volume; Létolle et al., this volume; VergnaudGrazzini et al., this volume). Further erosional events clearly took place in Plio-Pleistocene time at Site 406.

\section{CONCLUSION}

The geological history of Sites 403-406 and Sites 116-117 together with the regional seismic data document the transition from rifting to spreading, post-rift subsidence history, and the influence of changing ocean circulation regimes on the stratigraphy of margin sediments. The results emphasize the necessity for further drilling and geophysical studies to examine the nature of a continent/ ocean boundary formed in shallow depths and the tectonics of transforms at passive margins. Lastly, but by no means least, high-resolution lithologic and biostratigraphic studies are required to define the development of rapid changes in ocean circulation regimes.

\section{ACKNOWLEDGMENTS}

We wish to acknowledge our shipboard and shoreside colleagues for many useful discussions. D.G.R. thanks the Department of Energy for funding site surveys, well logging, and his participation in the Leg 48 studies. L.M. thanks the CEPM for permission to publish parts of the post-drilling survey and colleagues at the IFP for discussion and assistance.

\section{REFERENCES}

Bott, M.H.P., Browitt, C.W.A., and Stacey, A.P., 1971. The deep structure of the Iceland-Faeroes Ridge, Mar. Geophys. Res., v. 1, p. 328-351.

Bott, M.H.P., Sunderland, J., Smith, P.J., Casten, U., and Saxon, S., 1974. Evidence for continental crust beneath the Faeroe Islands, Nature, London, v. 248, p. 202-204.

Bullard, E.C., Everett, J.E., and Smith, A.G., 1965. The fit of the continents around the Atlantic, Phil. Trans. Roy. Soc. London, v. 258 , p. $41-51$

Casten, U., 1973. The crust beneath the Faeroe Islands, Nature, London, v. 241, p. 83-84.

Casten, U. and Nielsen, P.H., 1975. Faeroe Islands microcontinental fragment, J. Geophys., v. 41, p. 357-366. 
De Charpal, O., Guennoc, P., Montadert, L., and Roberts, D.G., in press. Rifting, Crustal Attenuation and subsidence in the Bay of Biscay, Nature.

Detrick, R.S., Sclater, J.G., and Thiede, J., 1977. Subsidence of aseismic ridges, Earth Planet. Sci. Lett., v. 34, p. 185-196.

Ewing, M. and Ewing, J., 1958. Seismic refraction measurements in the Atlantic Ocean Basins, in the Mediterranean Sea, on the Mid-Atlantic Ridge and in the Norwegian Sea, Geol. Soc. Am. Bull., v. 70, p. 291-318.

Gaskell, T.F., Hill, M.N., and Swallow, J.C., 1958. Seismic measurements made by HMS Challenger in the Atlantic, Pacific and Indian oceans and in the Mediterranean Sea, 1950-53, Phil. Trans. Roy. Soc. London, v. 251, p. 23-83.

Haigh, B.I.R., 1973. North Atlantic oceanic topography and lateral variations in the upper mantle, Geophys. J. Roy. Astron. Soc., v. 33, p. 405-420.

Jacque, M. and Thouvenin, J., 1975. Lower Tertiary tuffs and volcanic activity in the North Sea. In Woodland, A.W. (Ed.), Petroleum and the Continental Shelf of North West Europe: London (Applied Science Publishers), p. 455-466.

Johnson, G.L., Vogt, P.R., and Schneider, E.D., 1971. Morphology of the north eastern Atlantic and Labrador Sea, Deutsch. Hydrog. Zeitschr., v. 24, p. 49-73.

Jones, E.J.W., Ewing, M., Ewing, J.I., and Eittreim, S., 1970. Influences of Norwegian Sea overflow water on sedimentation in the northern Atlantic and Labrador Sea, J. Geophys. Res., v. 75 , p. $1655-1680$.

Kristoffersen, Y. and Talwani, M., 1978. The extinct triple junction south of Greenland and Tertiary motion of Greenland relative to North America, Geol. Soc. Am. Bull., v. 88, p. 1037-1049.

Laughton, A.S., 1971. South Labrador Sea and the evolution of the North Atlantic, Nature, London, v. 232, p. 612-617.

Laughton, A.S., Berggren, W., et al., 1972. Initial Reports of the Deep Sea Drilling Project, v. 12: Washington (U.S. Government Printing Office).

Le Pichon, X., Hyndman, R., and Pautot, G., 1972. Geophysical study of the opening of the Labrador Sea, J. Geophys. Res., v. 76 , p. 2891-2895.

Le Pichon, X., Bonnin, J., and Francheteau, J., 1977. Plate tectonics: Amsterdam (Elsevier Publ. Co.).

Miller, J.M., Roberts, D.G., and Matthews, D.H., 1973. Rocks of Grenville Age from Rockall Bank, Nature, Phys. Sci., v. 246 , p. 61.

Montadert, L., Roberts, D.G., et al., 1977. Rifting and subsidence on passive continental margins in the N.E. Atlantic, Nature, London, v. 268, p. 305-309.

Olivet, J.L., Le Pichon, X., Monti, S., and Sichler, B., 1974. Charlie Gibbs Fracture Zone, J. Geophys. Res., v. 79, p. 2059-2073.

Roberts, D.G., 1969. A new Tertiary volcanic centre on the Rockall Bank, Nature, London, v. 223, p. 819-820.

1970. Recent geophysical investigations on the Rockall Plateau and adjacent areas, Geol. Soc. London Proc., v. 1662 , p. $87-93$.

1971. New geophysical evidence on the origins of the Rockall Plateau and Trough, Deep-Sea Res., v. 18, p. 353-359.

1974. Structural development of the British Isles, continental margin and the Rockall Plateau. In Burk, C.A. and Drake, C.L. (Eds), The geology of Continental Margins: New York (Springer-Verlag), p. 343-359.

, 1975. Marine geology of the Rockall Plateau and Trough, Phil. Trans. Roy. Soc. London, v. 278, p. 447-509.

Roberts, D.G. and Jones, M.T., 1975. Magnetic Anomalies in the N.E. Atlantic, Astr. Meeting Europ. Geol. Soc. Reading.
Roberts, D.G., Ardus, D.A., and Dearnley, R., 1973. Pre-Cambrian rocks drilled from the Rockall Bank, Nature, Phys. Sci., v. 244 , p. 21-23.

Roberts, D.G., Bishop, D.G., Laughton, A.S., Ziolkowski, A., Scrutton, R.A., and Matthews, D.H., 1970. A newly discovered sedimentary basin on the Rockall Plateau, Nature London, v. 225, p. 170-172.

Roberts, D.G., Flemming, N.C., Harrison, R.K., and Binas, P., 1973. Helen's Reef; a Cretaceous microgabbroic intrusion in the Rockall intrusive centre, Mar. geol., v. M21-M30.

Roberts, D.G., Matthews, D.H., and Eden, R.A., 1972. Metamorphic rocks from the southern end of Rockall Bank, $J$. Geol. Soc. London, v. 128, p. 501-506.

Ruddiman, W.B., 1972. Sediment distribution on the Reykjanes Ridge; seismic evidence, Geol. Soc. Am. Bull., v. 83, p. 2039-2062.

Sabine, P.A., 1955. The geology of Rockall North Atlantic, Geol. Surv. Gt. Br. Bull., v. 16, p. 156.

Schreiber, E. and Fox, P.J., 1976. Compressional wave velocities and mineralogy of fresh basalts from the FAMOUS area and the Oceanographer Fracture Zone and the texture of layer $2 \mathrm{~A}$ of the oceanic crust, J. Geophys. Res., v. 81, p. 4071-4076.

Sclater, J.G., Anderson, R.N., and Bell, M.L., 1971. Elevation of ridges and evolution of the central eastern Pacific, $J$. Geophys. Res., v. 76, p. 7888-7915.

Scrutton, R.A., 1970. Results of a seismic refraction experiment on Rockall Bank, Nature, London, v. 227, p. 826-827.

1972. The Structure of Rockall Plateau microcontinent, Geophys. J. Roy. Astron. Soc., v. 27, p. 259-275.

Scrutton, R.A. and Roberts, D.G., 1971. Structure of the Rockall Plateau and Trough, north east Atlantic. In ICSU/SCORWG3 Symposium Cambridge 1970: The geology of the east Atlantic continental margin, Inst. Geol. Sci., Rept. 70/14, v.2, p. $77-87$

Srivastava, S.P., 1978. Evolution of the Labrador Sea and its bearing on the early evolution of the North Atlantic, Geophys. J. Roy. Astron. Soc., v. 52, p. 313-357.

Talwani, M. (Ed.), 1974. Lamont-Doherty survey of the World Ocean Underway marine geophysical data in the North Atlantic, June 1961-1971. Parts E and F - Seismic Reflection Profiles.

Talwani, M., Udintsev, G., et al., 1977. Initial Reports of the Deep Sea Drilling Project, v. 38: Washington (U.S. Government Printing Office).

Thiede, J., in press. Palaeoceanography, margin stratigraphy and palaeophysiography of the Tertiary North Atlantic and Norwegian-Greenland seas, Phil. Trans. Roy. Soc. London.

Veevers, J.J., 1977. Palaeobathymetry of the crest of spreading ridges related to the age of the ocean basins, Earth. Planet Sci. Lett., v. 34, p. 100-106

Vogt, P.R., 1972. The Faeroe-Greenland-Iceland Ridge and the Western Boundary Undercurrent, Nature, London, v. 239, p. 79-81.

Vogt, P.R. and Avery, O.E., 1974. Detailed magnetic surveys in the north east Atlantic and Labrador Sea, J. Geophys. Res. v. 79 , p. $363-389$

Vogt, P.R., Johnson, G.L., Holcombe, T.L., Gilg, J.G., and Avery, O.E., 1971. Episodes of sea floor spreading recorded by the North Atlantic Basement, Tectonophysics, v. 12, p. 211-234.

Watts, A.B., Schreiber, B.C., and Habib, D., 1975. Dredged rocks from the Hatton Bank, Rockall Plateau, J. Geol. Soc., v. 131, p. 639-646.

Ziegler, W., 1975. Outline of the geological history of the North Sea. In Woodland, A.W. (Ed.), Petroleum and the continental shelf of north-west Europe: London (Applied Science Publishers), p. 165-190. 